\title{
Geochemistry and petrogenesis of acidic volcanics from Betul-Chhindwara Belt, Central Indian Tectonic Zone (CITZ), central India
}

\author{
Ibrahim Yousuf ${ }^{1, *}$, D V Subba Rao ${ }^{2}, \mathrm{~S} \mathrm{Balakrishnan}^{3}$ and Talat Ahmad ${ }^{4}$ \\ ${ }^{1}$ Department of Geology, University of Delhi, Delhi 110 00\%, India. \\ ${ }^{2}$ CSIR-National Geophysical Research Institute, Hyderabad 500 007, India. \\ ${ }^{3}$ Department of Earth Sciences, Pondicherry University, Puducherry 605 014, India. \\ ${ }^{4}$ Vice Chancellors Office, University of Kashmir, Srinagar 190 006, India. \\ *Corresponding author.e-mail: yousuf1158@gmail.com
}

MS received 15 May 2019; revised 5 July 2019; accepted 10 July 2019

Betul-Chhindwara belt is part of Central Indian Tectonic Zone (CITZ) that includes Proterozoic basalt, rhyolite, quartzite, mafic-ultramafic rocks, volcano sediments and banded iron formation (BIF). Studied rhyolites and leuco-micro granites are deformed due to shearing and includes quartz, K-feldspar (microcline), muscovite, biotite and epidote. In some samples, feldspar has been sericitized due to interaction with hydrothermal fluids. The major element geochemistry of volcanic rocks clearly indicates acidic nature and falls in the rhyolite field. Rhyolites show difference in the enrichment of REEs and major element composition which help us divide them into two groups and also indicate heterogenous source. The rhyolites show very strong negative Eu anomaly, which indicates fractionation of feldspar. Positive anomalies of U-Th-Zr for the rhyolites indicate crustal involvement. The $\varepsilon N d t(t=1500)$ for the Group I rhyolites vary from -1.42 to -0.19 and for the Group II rhyolites vary from -5.81 to +0.14 and DM model ages for Group I rhyolites vary from 2284 to $2464 \mathrm{Ma}$ and for Group II vary from 2174 to $2863 \mathrm{Ma}$. It is suggested that contemporary mafic magma of the Betul-Chhindwara belt while ascending from mantle sources interacted with the continental crust at different levels, supplying heat and fluids which reduced the melting points of the crustal source rocks, producing felsic melt of varying compositions. Tectonic discriminant diagrams and geochemical data indicate subduction zone tectonic environment for the genesis of the Betul-Chhindwara acidic volcanism. The acidic volcanics of Betul-Chindwara, Sakoli and the Bijli rhyolites from the adjoining areas display similarity in terms of the total alkali vs. silica diagram and many of the major and trace elements, including rare earth element characteristics. Compared to Betul Rhyolite, Sakoli Rhyolites are derived from less enriched source with less involvement of crust and/or the latter represents high degree of partial melting of similar source. They are considered contemporaneous to Betul Rhyolite based on geochronological data. Contrastingly, Bijli Rhyolite show highly fractionated patterns with high LREE enrichment indicating considerable crustal involvement which is very obvious for within plate magmatism, assigned for the Bijli rhyolites.

Keywords. Betul-Chhindwara belt; acid volcanics; Sm-Nd and Rb-Sr isotopes; trace elements; CITZ. 


\section{Introduction}

Mesoproterozoic volcanic rocks form a dominant part of the ENE-WSW trending Central Indian Tectonic Zone (CITZ) (figure 1a), which is a complex orogenic belt formed by the juxtaposition of the southern Bastar Craton with the northern Bundelkhand Craton during the Proterozoic period (Radhakrishna and Ramakrishnan 1988; Radhakrishna and Naqvi 1986; Acharyya 2000). Acidic volcanism has been reported from several parts of the world with different geological history. CITZ contain Proterozoic supracrustal belts of varied metamorphic grades set in largely undifferentiated migmatitic gneisses and syn- to post-kinematic granitoids (Radhakrishna and Naqvi 1986; Acharyya 2000). CITZ is made up of terrains formed as a result of collision tectonics and accretion (Radhakrishna and Naqvi 1986; Yedekar 1990).

Generally, acidic volcanism is related to either continental rift or continental arc setting in which magma derived from the mantle sources come in contact with crustal sources at variable depths that partially melts to produce felsic melts. These hot, mantle derived magmas cause tensional regime in the crust/arc region (Ahmad et al. 2009a, b). These mafic plutonic bodies supply heat and fluids, that allows partial melting of the crustal/arc sources to give rise to felsic melts, thus both felsic and mafic melts erupts simultaneously giving rise to bimodal volcanism (Ahmad et al. 2009a, b).

The CITZ is covered to a large extent, by Gondwana sediments, Quaternary alluvium and Deccan traps. The extensive gneissic terrain encloses three sub-parallel, E-W trending supracrustal belts, separated from each other by crustal scale ductile shear zones, closely associated with granulite belts consisting of a string of granulite boudins (Ramakrishnan and Vaidyanadhan 2008). The supracrustal belts are Mahakoshal belt in the north, Betul-Chhindwara belt in the middle and the Sausar-Sakoli belt in the south (figure 1b).

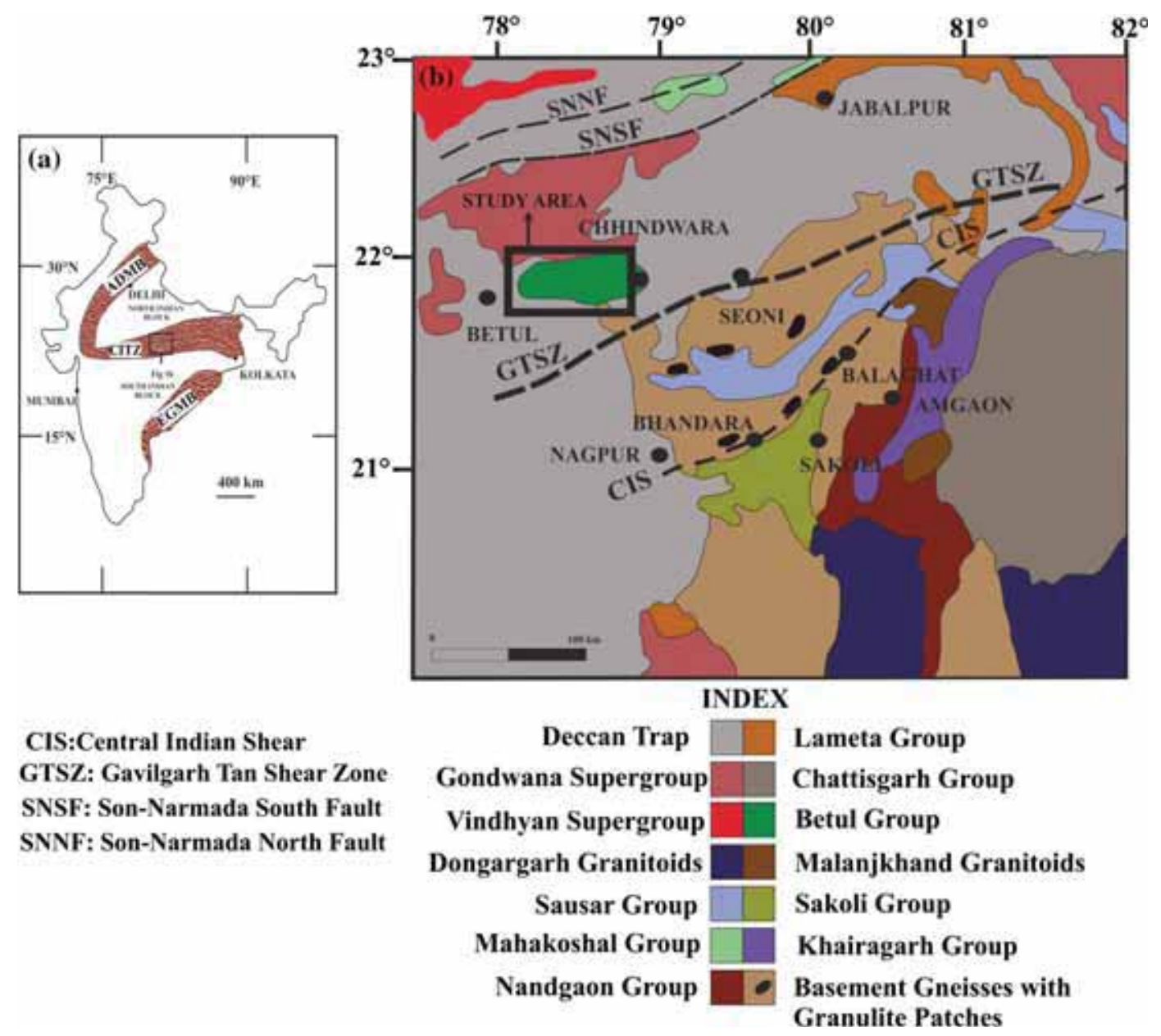

Figure 1. (a) Outline map of India showing Aravali Delhi Mobile Belt (ADMB), Eastern Ghat Mobile Belt (EGMB), and Central Indian Tectonic Zone (CITZ) seperating north and south Indian block. (b) Simplified geological map of part of CITZ showing different fault zones and supracrustal belts (modified after Chattopadhyay et al. 2001; Ahmad et al. 2009b). 
There are numerous fault zones separating these supracrustal belts. The granulite belts are the Makrohar belt in the north, Ramakona-Katangi belt in the middle and Balaghat-Bhandara belt in the south. Sakoli bimodal volcanism has been reported from the southern part of the CITZ (Ahmad et al. 2009a, b). Sm-Nd whole rock age for the acidic volcanics of Sakoli Group is $1675 \pm 180 \mathrm{Ma}$ (Ahmad et al. 2009b). Bijli Rhyolite is well exposed on the Dongargarh volcanic sequence.

The rhyolite of the Betul-Chhindwara belt is an important unit of the CITZ. Present petrological study on the Betul-Chhindwara belt rhyolites is based on field relationship, petrography and geochemistry including major element, trace element and isotopic ( $\mathrm{Sm}-\mathrm{Nd}, \mathrm{Rb}-\mathrm{Sr})$ data. These data are useful in characterizing the rock and to understand their genesis, source characteristic and tectonic setting. Major element geochemistry is used to decipher rhyolitic nature of the volcanic rocks. Based on new geochemical data, Sm-Nd, and $\mathrm{Rb}-\mathrm{Sr}$ isotopic systematics, we have refined the existing evolutionary models for acidic volcanic rocks of the Betul-Chhindwara belt. The CITZ with its trans-continental status has significance in understanding the geodynamic process of crustal assembly in East Gondwanaland during Proterozoic Grenvillian orogeny (Roy and Prasad 2003).

\section{Regional geology}

In the central Indian Craton, the CITZ separates the Bundelkhand Craton in the north and Bastar Craton in the south (Radhakrishna and Naqvi 1986). In the east, CITZ continues to Chotanagpur gneissic complex and further northeast to Shillong Plateau, still eastern and western margins are not well defined (Ahmad et al. 2009b). CITZ has a long geological history from 2.2 to $0.9 \mathrm{Ga}$ (Roy and Prasad 2003). Jain et al. (1995) proposed the southward subduction of Bundelkhand Craton under Bastar Craton; however, Roy and Prasad (2003), Roy et al. (2001) proposed convergent plate tectonic model with northerly subduction of the Bastar Craton (BC) under the Bundelkhand Craton $(\mathrm{BKC})$ resulting ultimately in Proterozoic continent-continent collision, the Ramakona-Katangi Granulite Belt being the suture zone. The complex tectonic setting of CITZ can be deciphered by carrying out thorough geochemical and geochronological study of the belt. Every supra-crustal belt is marked by two sets of shear zones, one in the north and the other in the south. Betul-Chhindwara belt is sandwiched between Mahakoshal belt in the north and Sausar belt in the south (Ramakrishnan and Vaidyanadhan 2008). These belts are separated by shear zones, Son Narmada North Fault (SNNF) marks the northernmost extension of CITZ and Central Indian Shear (CIS) marks the southernmost extension (figure 1b). Betul-Chhindwara belt exposes both mafic and felsic volcanism. The width of Betul-Chhindwara belt ranges from $20-30 \mathrm{~km}$ approximately and is about $100 \mathrm{~km}$ in length, representing our study area. SNSF marks the northern extension (Nair 1995; Acharyya 2000; Roy and Prasad 2003; Yedekar et al. 2003) and Gavilgarh-Tan shear zone marks the southern extension of Betul-Chhindwara belt. The Betul-Chhindwara belt comprises various types of gneisses containing enclaves of amphibolites, quartzites, calc silicate, BIF, volcanic metasediments, bimodal volcanics (basalt-rhyolite), intrusive and extrusive suites of mafic-ultramafic rocks, and syntectonic granitoids. The rocks of Betul-Chhindwara have been deformed to low grade metamorphism. Geochemically rhyolites are similar to those generated in continental arc environment (Raut and Mahakud 2002).

Present study covers the Chhindwara and Betul districts of Madhya Pradesh, India. Felsic outcrops are found scattered within the Betul-Chhindwara supracrustal belt in linear pattern. The rocks show E-W trending foliation with steep dip of around $45^{\circ}-60^{\circ}$ north. The collision of two cratons, i.e., Bundelkhand Craton in the north and Bastar Craton in the south of CITZ caused deformation in the suture zone. The Sausar supracrustal belt has recorded an event at 1.0 Ga (Lippolt and Hautmann 1994) and highpressure granulite facies metamorphism (Bhowmik 1999; Bhowmik and Pal 2000), related to collisional tectonics in the CITZ. Rifting and collisional events are responsible for numerous volcanic eruptions in the belt which have not been studied in any details earlier. Tirodi gneiss which forms the basement for these supra-crustals gives a U-Pb zircon age of around $1618 \pm 8$ Ma (Bhowmik et al. 2011) and 1534 \pm 13 Ma (Ahmad et al. 2009a), which marks the magmatic crystallization age of protolith. This basement is overlain by Betul-Chhindwara belt rocks and Padhar mafic-ultramfic complex (PMUM) have intruded in the basement (Mishra et al. 2011). However, the relationship between 
Betul-Chhindwara belt volcanism and Padhar mafic-ultramafic complex (PMUM) is still not well understood.

Budelkhand Craton and Bastar Craton show different crustal evolutionary histories (Mondal et al. 2002), this is also reflected in different geological and geophysical characteristics (Qureshy and Iqbaluddin 1992; Verma and Banerjee 1992; Jagadeesh and Rai 2008). Betul-Chhindwara belt is comprised of varied rock types including mafic as well as felsic volcanics, which makes it different from the other two supracrustal belts, i.e., Mahakoshal and Sausar belt. Mahakoshal belt is basically rich in mafic volcanics with very little felsic volcanics, whereas Sausar Belt has very little mafic volcanics. Tectonism and erosion of Gondawana sediments and Deccan traps exposed the Betul-Chhindwara supracrustal belt.

\section{Petrographic characteristics}

Two varieties of rhyolite have been reported from the study area and they can be easily distinguished macroscopically. Though both of these are characterized by phenocryst of quartz and feldspar, they are distinguishable by the presence of muscovite and biotite bands in relatively finer grained variety and their absence in the fine-to-coarse rhyolites. Major mineral constituents of all the rhyolites are quartz, plagioclase feldspars, microcline, biotite, muscovite with minor proportion of Fe-Ti oxides, titanite and zircon and occasionally hornblende. Quartz grains are subhedral-to-anhedral with fused boundaries suggesting postcrystallization metamorphic effect. Inter-growth and inter-locking of quartz grains are preserved indicating eutectic crystallization. Texturally, the rhyolites are fine-grained and sericite-muscovite assemblage is very common. Presence of both plagioclase and microcline together suggests a subsolvus process (figure $3 \mathrm{~d}$ ) which is supported by exsolution lamellae in feldspar (figure 3c). Most of the rhyolite samples has experienced low grade of metamorphism and deformation. Rhyolites from central part near Dhelwada show occurrence of long impersistent band of biotite and muscovite crystals. Rhyolites from Bindrai (eastern part) and from Ranidongri (western part) show less deformation, and not much elongated crystal of biotite and muscovite are seen. Even these samples are comparatively coarser than the rhyolite samples from Dhelwada (central part) which show very prominent elongated crystals of biotite and muscovite. Biotite at places are seen altered to chlorite. Sericitization of feldspar is commonly observed suggesting post-magmatic fluid-rock interaction (figure $3 \mathrm{~b}$ ). Quartz veinlets can be also observed in some samples. Layer parallel deformation in the form of kinked biotite grains is also observed (figure 3a). Shortening of mica crystal parallel to compressive stress indicates compressional tectonic environment. CIPW Normative mineralogical calculation of these samples gives mineral composition of quartz 22.3-41.05, orthoclase 18.57-32.77 and plagioclase (anorthite + albite) 10.66-46.18. These felsic minerals all together constitutes about $90 \%$. Some of the samples with high quartz show less plagioclase composition. The mafic mineral hypersthene ranges from 1.1 to 11.9 and diopside varies from 3.06 to 14.47 together constituting $5-12 \%$ which confirms mafic constituents in some samples. Magnetite and ilmenite together vary from 1 to $4 \%$. Mineralogical compositions of these samples clearly indicate felsic nature and normative composition of quartz and hypersthene indicates that samples are oversaturated rocks.

\section{Analytical techniques}

Least altered samples were selected for the major and trace element analysis. All the major, trace element analysis and loss on ignition (LOI) were carried out at CSIR-National Geophysical Research Institute, Hyderabad. Samples were processed and powdered using a Tema-Mill at the Department of Geology, University of Delhi. Major element analyses were done using X-ray fluorescence spectrometry (XRF, Philips 1400) at CSIR-NGRI, Hyderabad. Trace elements were analyzed using high resolution Inductively Coupled Plasma Mass Spectrometer (HR-ICP-MS; Nu Instruments Attom, UK) at the CSIR-NGRI, Hyderabad. For XRF analyses, pressed pellets using boric powder base was used to prepare the pellets for major element analysis. For ICP-MS analyses, $50 \mathrm{mg}$ sample powder were digested using several concentrated acids digestion technique following the procedures of Balaram (1996). International rock standards were used for meta-basalts and rhyolites. In ICP-MS analyses, JR-2 and BHVO-1 were used for the rhyolites and metabasalts respectively, the precision obtained is better than $10 \%$ RSD. Isotopic analysis for the selected samples was carried out using a Thermal 


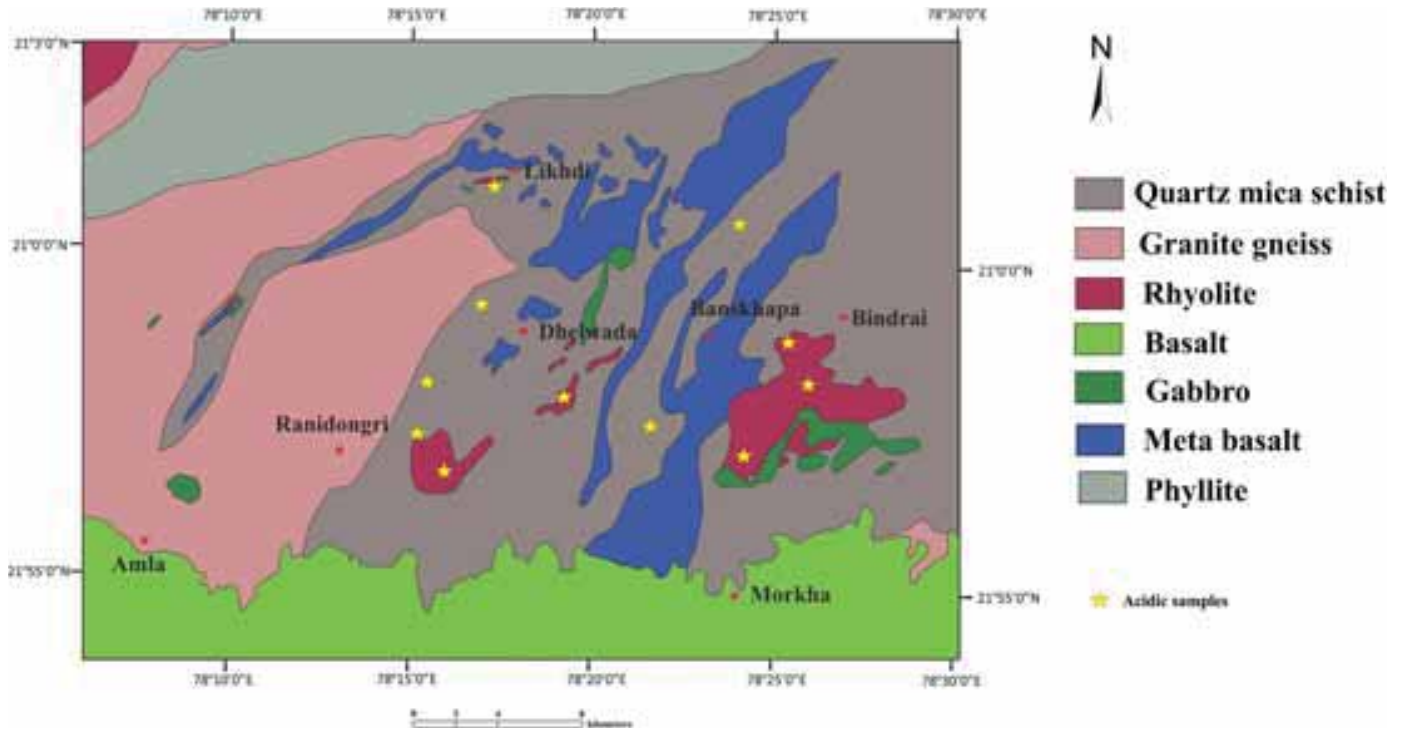

Figure 2. Geological map of Betul-Chhindwara belt on 50,000 scale published by Geological Survey of India, showing lithological units and sample locations.

(a)

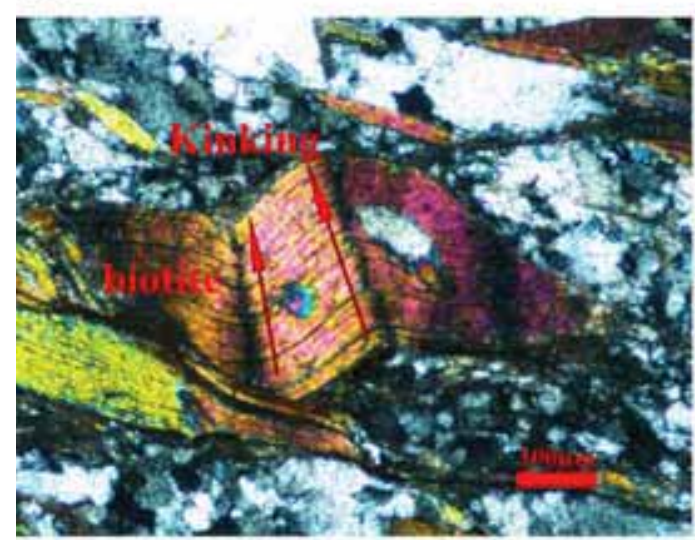

(c)

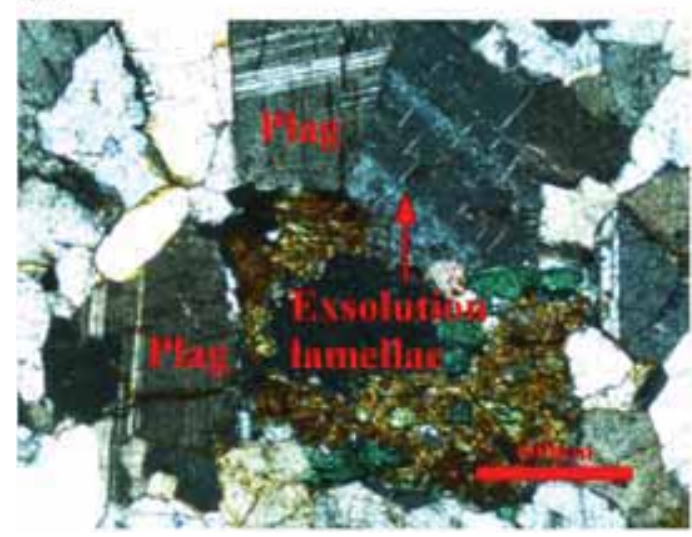

(b)

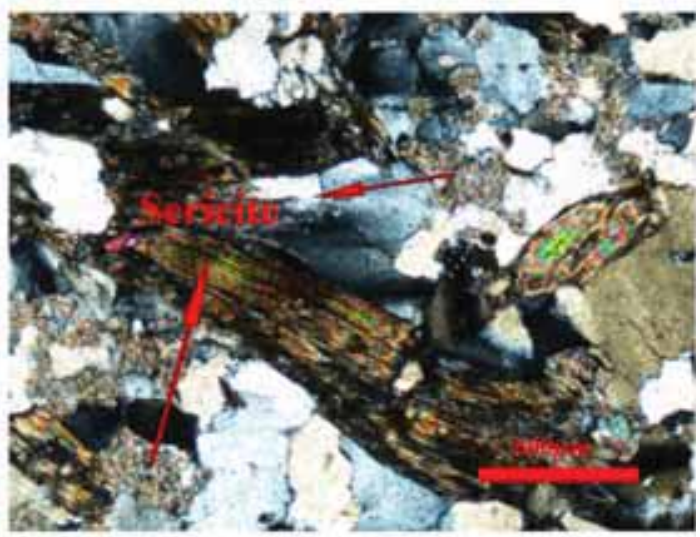

(d)

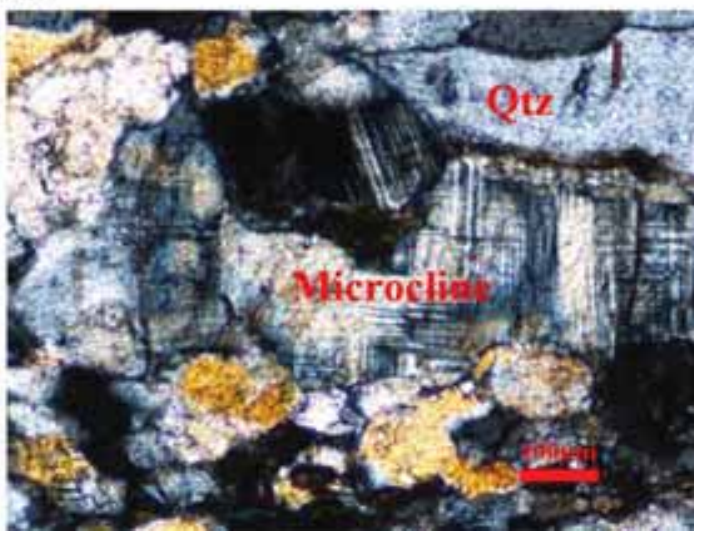

Figure 3. (a) Photomicrograph of kinked biotite crystal present in Betul Rhyolite. (b) Photomicrograph of sericitized rhyolite which confirms hydrothermal fluid interaction. (c) Exsolution lamellae in feldspar with plagioclase. (d) Few samples show microcline with plagioclase indicating sub-solvus process.

Ionization Mass Spectrometer (TIMS, model-Triton, Thermo-Finnigan) at the Department of Earth Sciences, Pondicherry University, India. The
${ }^{143} \mathrm{Nd} /{ }^{144} \mathrm{Nd}$ ratio measured on AMES during the sample analysis is $0.511973+-0.000006$ ( 1 s.d.; $\mathrm{n}=10$ ) (Kingson et al. 2017). 

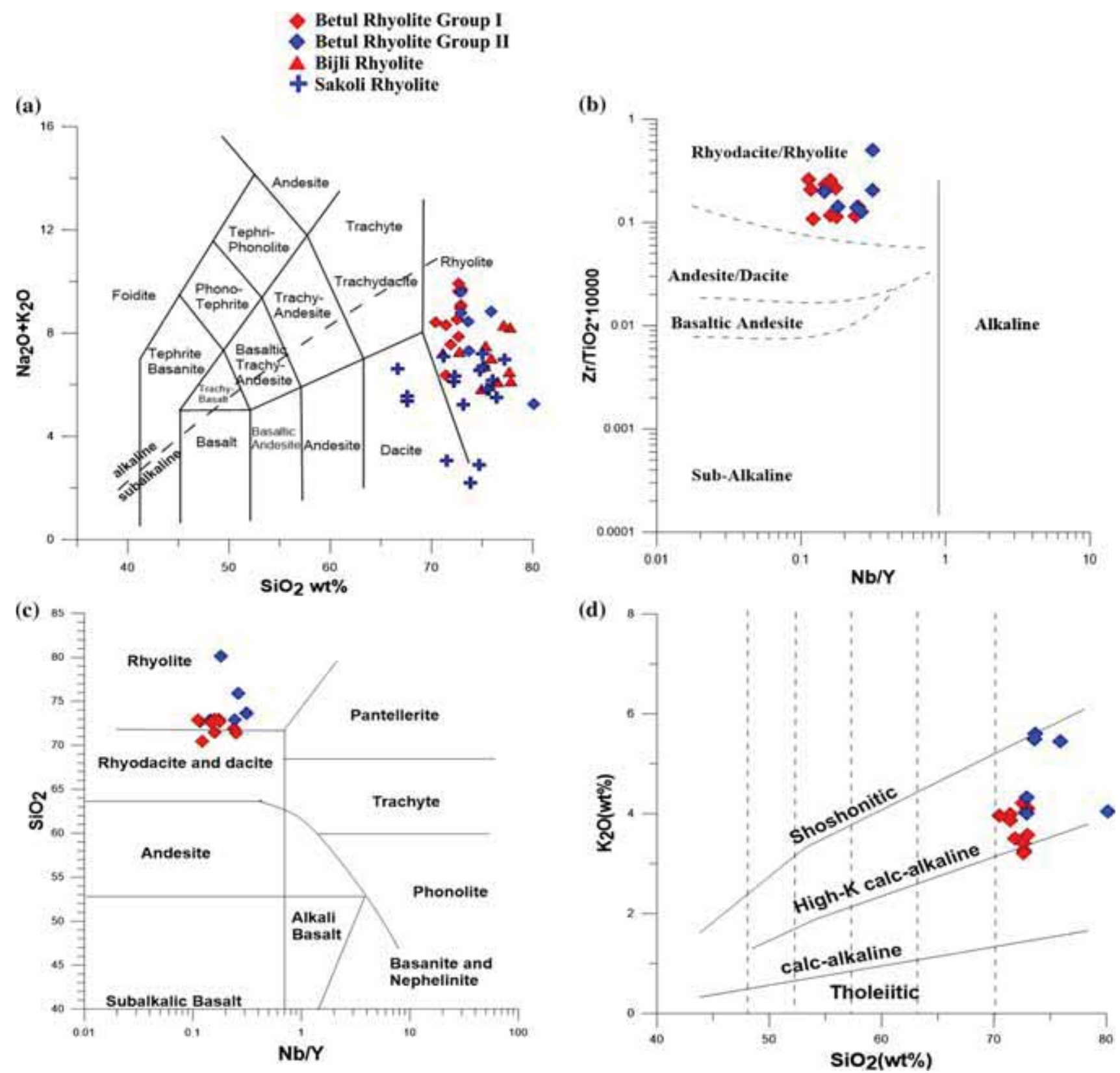

Figure 4. (a) $\mathrm{SiO}_{2}$ vs. $\mathrm{Na}_{2} \mathrm{O}+\mathrm{K}_{2} \mathrm{O}$ (TAS diagram, Le Bas et al. 1986) shows Betul Rhyolite (present study), Sakoli Rhyolite (Ahmad et al. 2009b) and Bijli Rhyolite (Sensarma et al. 2004). (b and c) Geochemical discrimination diagrams show the subalkalic and bimodal nature of the Betul volcanics (Winchester and Floyd 1977). (d) $\mathrm{K}_{2} \mathrm{O}-\mathrm{SiO}_{2}$ diagram of Peccerillo and Taylor (1976).

\section{Major element geochemistry}

All the rhyolites from Bindrai, Ranidongri and Dhelwada (figure 2) have high $\mathrm{SiO}_{2}$ composition, i.e., majority of the samples plot in rhyolite field of the TAS diagram (figure 4a) and are sub alkaline in nature (figure 4b). On the basis of difference in major and trace element concentration, rhyolite have been divided into two groups (table 1). Group I rhyolite shows high silica and enriched REE concentration compared to Group II rhyolites.
$\mathrm{SiO}_{2}$ content of Group I (70.45-72.98 wt\%) is low compared to Group II (72.88-80.11 wt\%). Chemical composition of all other oxides for both the groups is quite different (table 2). Group I rhyolites show comparatively high $\mathrm{Fe}_{2} \mathrm{O}_{3}, \mathrm{MgO}, \mathrm{TiO}_{2}$, $\mathrm{Na}_{2} \mathrm{O}$, and $\mathrm{CaO}$ concentration with respect to Group II rhyolites (figure 5). But it is observed that $\mathrm{K}_{2} \mathrm{O}$ and $\mathrm{Al}_{2} \mathrm{O}_{3}$ have high concentration in Group II rhyolites (figures 5 and 6b). Although both the groups show difference in chemical composition, they follow the similar trend when major 
Table 1. Sample location of Betul Rhyolite, CITZ, central India.

\begin{tabular}{|c|c|c|c|c|}
\hline Sample & Location & Description & Latitude & Longitude \\
\hline \multicolumn{5}{|c|}{ Rhyolite Group I } \\
\hline BS18 & Bindrai & High silica \& Zr, less enriched REE & $\mathrm{N} 21^{\circ} 58^{\prime} 47.0^{\prime \prime}$ & $\mathrm{E} 78^{\circ} 25^{\prime} 53.6^{\prime \prime}$ \\
\hline BS19 & Bindrai & High silica \& Zr, less enriched REE & $\mathrm{N} 21^{\circ} 58^{\prime} 49.0^{\prime \prime}$ & $\mathrm{E} 78^{\circ} 25^{\prime} 54.6^{\prime \prime}$ \\
\hline $\mathrm{BS} 21$ & Chordongri & High silica \& Zr, less enriched REE & $\mathrm{N} 21^{\circ} 58^{\prime} 29.6^{\prime \prime}$ & $\mathrm{E} 78^{\circ} 25^{\prime} 03.4^{\prime \prime}$ \\
\hline $\mathrm{BS} 23$ & Taroda & High silica \& Zr, less enriched REE & $\mathrm{N} 21^{\circ} 57^{\prime} 14.0^{\prime \prime}$ & $\mathrm{E} 78^{\circ} 24^{\prime} 20.9^{\prime \prime}$ \\
\hline BR12 & Ranidongri & High silica \& Zr, less enriched REE & $\mathrm{N} 21^{\circ} 57^{\prime} 26.1^{\prime \prime}$ & $\mathrm{E} 78^{\circ} 14^{\prime} 51.7^{\prime \prime}$ \\
\hline BR14 & Dhelwada & High silica \& Zr, less enriched REE & $\mathrm{N} 21^{\circ} 59^{\prime} 18.1^{\prime \prime}$ & $\mathrm{E} 78^{\circ} 15^{\prime} 32.7^{\prime \prime}$ \\
\hline $\mathrm{BR} 23$ & Ranidongri & High silica \& Zr, less enriched REE & $\mathrm{N} 21^{\circ} 57^{\prime} 43.7^{\prime \prime}$ & $\mathrm{E} 78^{\circ} 11^{\prime} 49.2^{\prime \prime}$ \\
\hline $\mathrm{BR} 26$ & Ranidongri & High silica \& Zr, less enriched REE & $\mathrm{N} 21^{\circ} 57^{\prime} 32.9^{\prime \prime}$ & $\mathrm{E} 78^{\circ} 13^{\prime} 19.3^{\prime \prime}$ \\
\hline $\mathrm{BR} 27$ & Ranidongri & High silica \& Zr, less enriched REE & $\mathrm{N} 21^{\circ} 57^{\prime} 33.2^{\prime \prime}$ & $\mathrm{E} 78^{\circ} 13^{\prime} 16.0^{\prime \prime}$ \\
\hline $\mathrm{BR} 28$ & Ranidongri & High silica \& Zr, less enriched REE & $\mathrm{N} 21^{\circ} 57^{\prime} 52.6^{\prime \prime}$ & $\mathrm{E} 78^{\circ} 13^{\prime} 31.6^{\prime \prime}$ \\
\hline $\mathrm{BR} 29$ & Dhelwada & High silica \& Zr, less enriched REE & $\mathrm{N} 21^{\circ} 58^{\prime} 53.3^{\prime \prime}$ & $\mathrm{E} 78^{\circ} 16^{\prime} 16.9^{\prime \prime}$ \\
\hline \multicolumn{5}{|c|}{ Rhyolite Group II } \\
\hline $\mathrm{BS} 22$ & Nimoti & Low silica \& Zr, enriched REE & $\mathrm{N} 21^{\circ} 57^{\prime} 14.0^{\prime \prime}$ & $\mathrm{E} 78^{\circ} 24^{\prime} 20.9^{\prime \prime}$ \\
\hline BR6 & Taroda & Low silica \& Zr, enriched REE & $\mathrm{N} 21^{\circ} 58^{\prime} 15.3^{\prime \prime}$ & $\mathrm{E} 78^{\circ} 19^{\prime} 49.0^{\prime \prime}$ \\
\hline BR11 & Jambada & Low silica \& Zr, enriched REE & $\mathrm{N} 21^{\circ} 56^{\prime} 33.5^{\prime \prime}$ & $\mathrm{E} 78^{\circ} 14^{\prime} 16.2^{\prime \prime}$ \\
\hline BR15 & Dhelwada & Low silica \& Zr, enriched REE & $\mathrm{N} 21^{\circ} 59^{\prime} 24.1^{\prime \prime}$ & $\mathrm{E} 78^{\circ} 15^{\prime} 31.9^{\prime \prime}$ \\
\hline BR30 & Dhelwada & Low silica \& Zr, enriched REE & $\mathrm{N} 21^{\circ} 58^{\prime} 50.7^{\prime \prime}$ & $\mathrm{E} 78^{\circ} 16^{\prime} 43.9^{\prime \prime}$ \\
\hline ET3 & Etawa & Low silica \& Zr, enriched REE & $\mathrm{N} 21^{\circ} 59^{\prime} 56.0^{\prime \prime}$ & $\mathrm{E} 78^{\circ} 22^{\prime} 46.1^{\prime \prime}$ \\
\hline
\end{tabular}

oxides are plotted against $\mathrm{SiO}_{2}$ wt\% (figure 5). $\mathrm{Fe}_{2} \mathrm{O}_{3}$ wt\%, $\mathrm{TiO}_{2}$ wt $\%$ and $\mathrm{MgO}$ wt\% decrease with the increase in the $\mathrm{SiO}_{2}$ concentration. Both the groups show a calc-alkaline trend on the AFM diagram of Irvine and Baragar (1971) (figure 6d). Rhyolitic samples show high-K calc-alkaline nature in $\mathrm{SiO}_{2}$ vs. $\mathrm{K}_{2} \mathrm{O}$ (wt\%) diagram after Peccerillo and Taylor (1976) (figure 4d). Group II samples are high $\mathrm{K}$ rhyolites $\left(\mathrm{K}_{2} \mathrm{O}=4-5.49 \mathrm{wt} \%\right)$ compared to Group I rhyolites $\left(\mathrm{K}_{2} \mathrm{O}=3.2-4.2 \mathrm{wt} \%\right)$. Alkali content and $\mathrm{SiO}_{2}$ concentration of Betul Rhyolites are very similar to the Sakoli acidic volcanics (Ahmad et al. 2009b) and Bijli Rhyolite (Sensarma et al. 2004) from the nearby areas. Alkali content $\left(\mathrm{K}_{2} \mathrm{O}+\mathrm{Na}_{2} \mathrm{O}\right)$ of the Betul Rhyolite vary from 6.37 to $9.9 \mathrm{wt} \%$, also observed in Bijli Rhyolite from the adjoining area where $(\mathrm{K} 2 \mathrm{O}+\mathrm{Na} 2 \mathrm{O})$ varies from 8 to $10 \mathrm{wt} \%$ and goes up to $12 \mathrm{wt} \%$ (Sensarma et al. 2004). In the QAP (quartz-alkali feldspar-plagioclase) diagram (figure 5b), most samples plot in the dacite field. Samples of dacite field belongs to Group I rhyolite (low $\mathrm{SiO}_{2}$, high $\mathrm{Na}_{2} \mathrm{O}$ and $\mathrm{CaO}$ ) with low quartz and high palgioclase. Group II rhyolite samples (high $\mathrm{SiO}_{2}$, low $\mathrm{Na}_{2} \mathrm{O}$ and $\mathrm{CaO}$ ) such as BR-6, BR-11, BR-30 and ET-3 with high silica and low plagioclase plot from rhyo-dacite to rhyolite field. In the An-Ab-Or diagram (figure 5c) for plutonic rock, all the samples plot in the granite field with very low anorthite composition. Albite composition vary from 29.7 to $70.31 \%$ and orthoclase composition from 29.6 to $69.42 \%$.
TAS diagram for felsic volcanic rock and plutonic rock share the same field for rhyolite and granite, which can be also applied to An-Ab-Or diagram assuming same field for granite and rhyolite.

For both the groups of rhyolites, $\mathrm{Zr}$ decreases significantly with increase in $\mathrm{SiO}_{2}$ (figure 6b). This behaviour can be explained due to fractionation crystallization of zircon. But the zircon concentration in both the groups are different. Group I has higher zircon concentration $(\mathrm{Zr}=317-721$ ppm) compared to Group II with lower concentration of zircon ( $\mathrm{Zr}=115-569 \mathrm{ppm})$. This difference in zircon concentration can be explained by the following possibilities: (1) there may be two different sources depicting source heterogeneity and (2) because of zonation within the magma chamber (Van Wagoner et al. 2002). However, in all other variation diagrams both the groups show distinct trends indicating different sources for them.

\section{Trace element characteristics}

Samples of both the groups of rhyolites show consistent and complementary trends in the REE diagrams (figure 8a). Both the groups are moderately fractionated with enriched Light Rare Earth Elements (LREE) and a very prominent negative europium (Eu) anomaly is observed (figure 8a). Group I with higher $\mathrm{Zr}$ concentration shows 


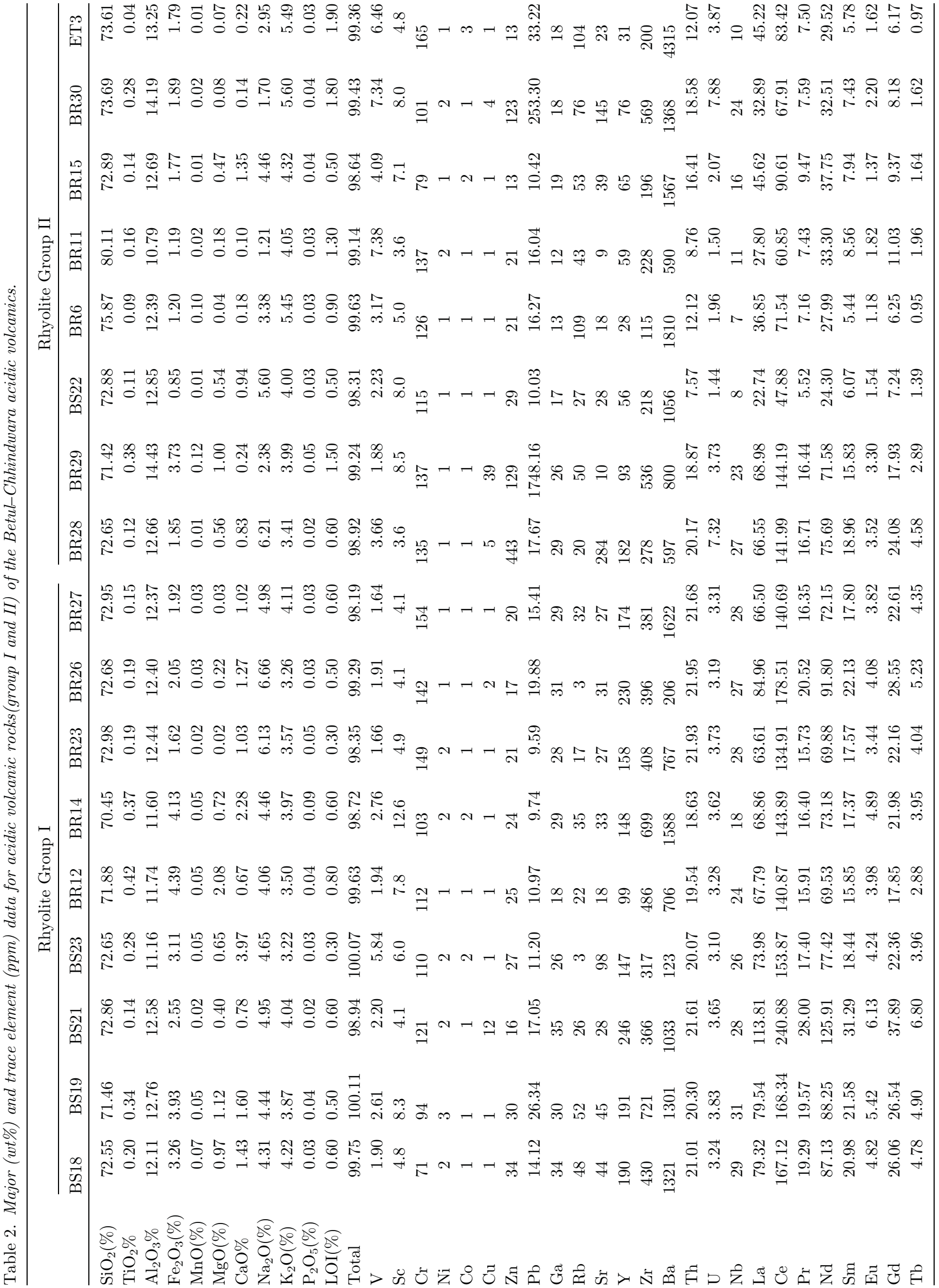


enriched LREE, which is 200-350 times chondritic abundance. But Group II rhyolites have lesser abundance of LREE than Group I rhyolites, which is 70-150 times chondritic abundance. The heavy rare-earth elements (HREE) abundance of Group I rhyolites ranges from 50 to 110 times chondritic abundance and for Group II rhyolites, it ranges from 18 to 52 times chondritic abundance. Two samples (BR-12 and BR-29) from Group I have slightly lesser HREE, which could be possible because of the fractionation of amphiboles.

Multi-elemental pattern for both the series of rhyolite, i.e., Group I and Group II have similar elemental variation (figure 8b). In Group I, large ion lithophile elements (LILE) such as Th, U, K, $\mathrm{Ba}$, and $\mathrm{Rb}$ show enriched characteristic with a strong positive anomaly of $\mathrm{K}$. U exhibit slight negative anomaly compared to neighbouring element Th. The high field strength elements (HFSE) such as $\mathrm{Nb}$ and $\mathrm{Ti}$ show a strong negative anomaly. Group II rhyolites show a similar pattern with more enriched LILEs than Group I having same positive $\mathrm{K}$ anomaly. Samples of Group II also exhibit negative anomaly for HFSE such as $\mathrm{Nb}$ and Ti. Negative anomaly of Sr can be found in both the groups of rhyolites (figure $8 \mathrm{~b}$ ).

\section{Petrogenesis}

There are several models to explain the genesis of within plate magma in a continental area, some of them are AFC model (assimilation and fractional crystallization) (e.g., DePaolo 1981; Dupuy and Dostal 1984; Thompson et al. 1984; Cox and Hawkesworth 1985; Marsh 1989; Fodor et al. 1990), RTF model (replenished, tapped, and fractionated magma) (Cox 1988; Hogg et al. 1989; O'Hara and Matthews 1981), and mantle metasomatism prior to partial melting (Dostal et al. 1989; Pegram 1990; Sheth 1999). Out of these models, the most appropriate model is chosen on the basis of geochemical characteristics of the acidic volcanic rocks. The major element abundance clearly shows the sub-alkaline nature of the rhyolites in the Betul-Chindwara belt volcanic complex (figure 4b, c).

Plots of all the major oxides against $\mathrm{SiO}_{2}$ clearly show different concentrations for both the groups of rhyolites, which probably indicates different sources and/or different genetic histories for both the groups (figure 5). From $\mathrm{SiO}_{2}$ vs. $\mathrm{K}_{2} \mathrm{O}$ diagram, it is very clear that all the samples from both the 
(a)
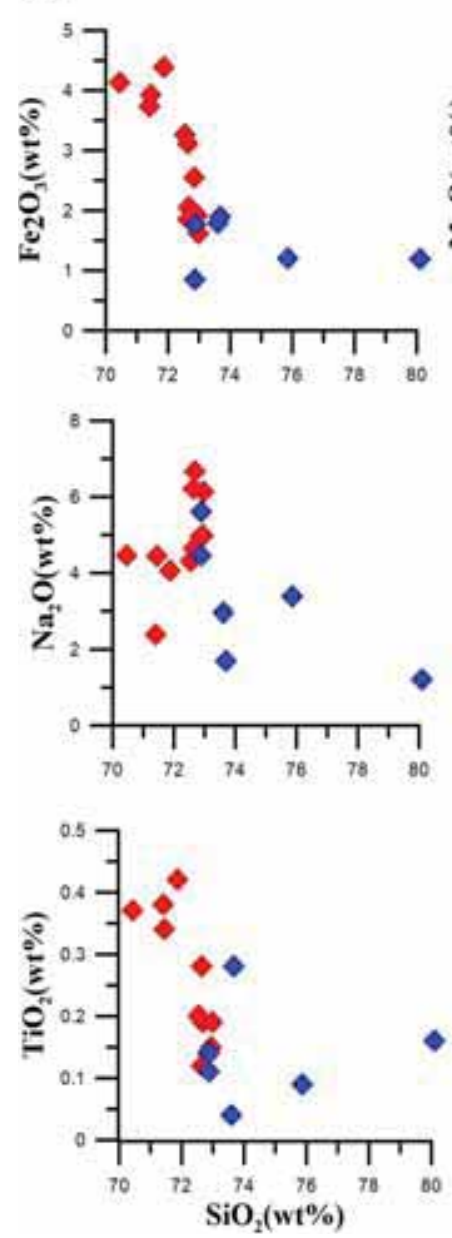
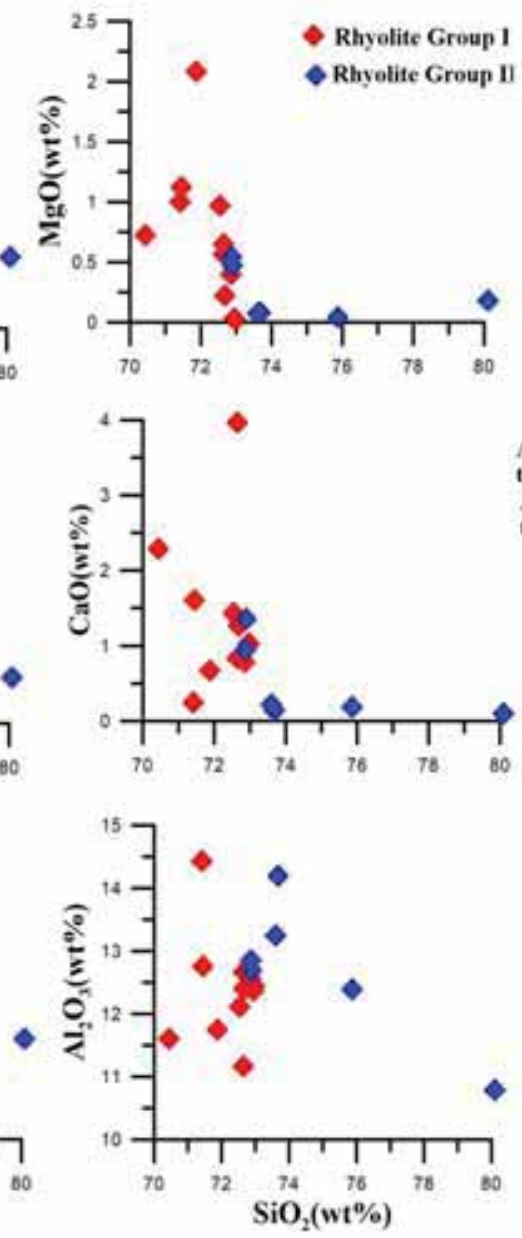

(b)

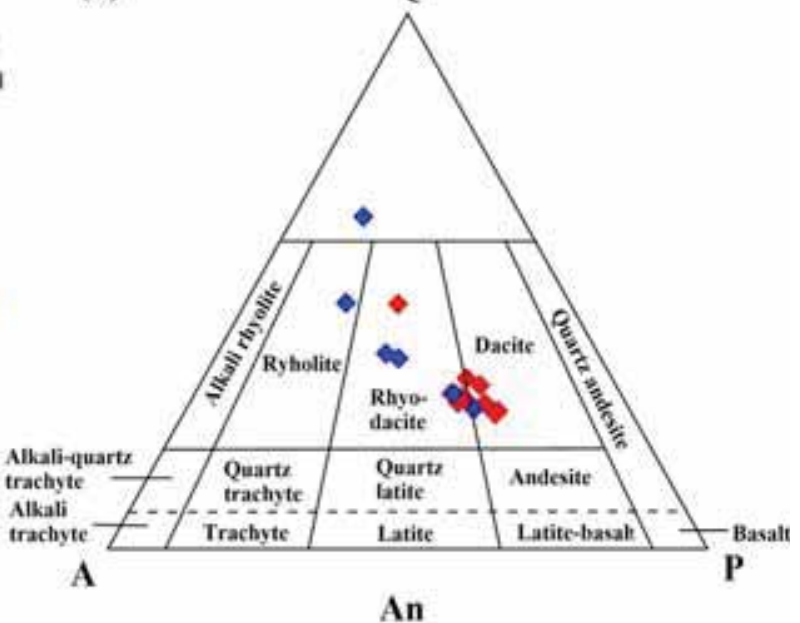

(c)

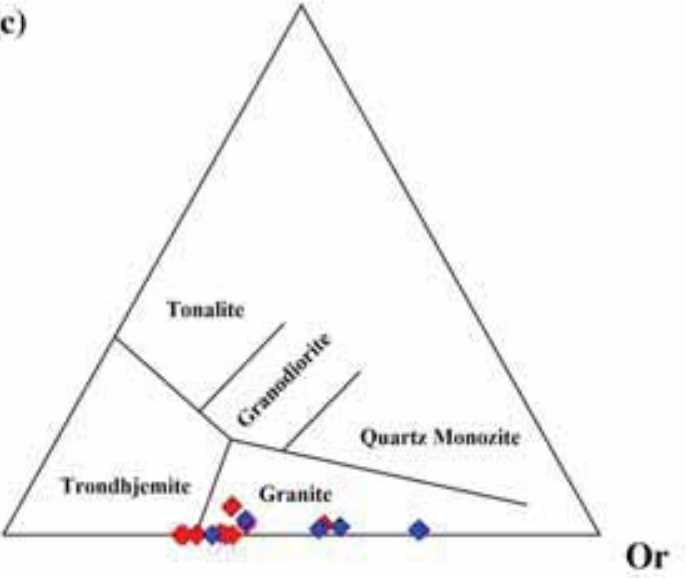

Ab

Figure 5. (a) Major element variation diagram against increasing $\mathrm{SiO}_{2}$ for both group of rhyolites which show different chemical composition. (b) IUGS classification on the basis of mineral composition in the QAP diagram after Le Maitre et al. (2002). (c) An-Ab-Or diagram shows samples in granite field which is plutonic equivalent of rhyolite.

groups are very rich in $\mathrm{K}$, but Group II is even richer in K (figure 4d). Acidic samples from Sakoli and Bijli Rhyolite have been also compared with the present-studied rocks as they all have similar chemical composition and they all belong to the CITZ belt. Study of all these volcanics will be very useful in constructing the tectonic setting of the CITZ belt. The binary (Harker) plots for the rhyolites show decrease in $\mathrm{P}_{2} \mathrm{O}_{5}$, which suggests fractionation of apatite. $\mathrm{TiO}_{2}$ and $\mathrm{Fe}_{2} \mathrm{O}_{3}$ also show a similar behaviour which suggests presence of iron titanium oxides (Van Wagoner et al. 2002) (figure 5). Decrease in $\mathrm{Zr}$ with the increase in the $\mathrm{SiO}_{2}$ can be seen in Betul Rhyolite, which explain the fractionation of zircon (figure $6 \mathrm{~b}$ ). It is very obvious that $\mathrm{Rb}-\mathrm{Ba}$ diagram (figure $6 \mathrm{c}$ ) and strong negative $\mathrm{Sr}, \mathrm{P}, \mathrm{Ti}$ anomalies (figure $8 \mathrm{~b}$ ) supports the fractionation of K-feldspar and plagioclase. Positive trend in the La-Nd diagram (figure 6a) depicts primary magma characteristics of the Betul Rhyolites.

Figure 8(a) displays the rare earth element (REE) pattern for Betul Rhyolite (both groups) with outline of Sakoli and Bijli Rhyolite. Both the groups of Betul Rhyolite follow the same REE pattern, but show difference in the total REE abundance indicating similar but heterogenous source. The large variation in the total REE abundance varying from 70 to 400 times the chondrite abundance indicates large variation in the degree of partial melting and/or effect of crustal contamination (Ahmad et al. 2008a, b). Group I samples are more enriched and are moderately fractionated and have moderate slope of $\mathrm{REE}$ with $(\mathrm{La} / \mathrm{Yb}) \mathrm{n}=2.3-4.7$ and $(\mathrm{Gd} / \mathrm{Yb}) \mathrm{n}=$ 0.9-1.5 which indicates not much residual garnet in the source. Whereas Group II rhyolite are comparatively less enriched and have moderate slope of 
(a)

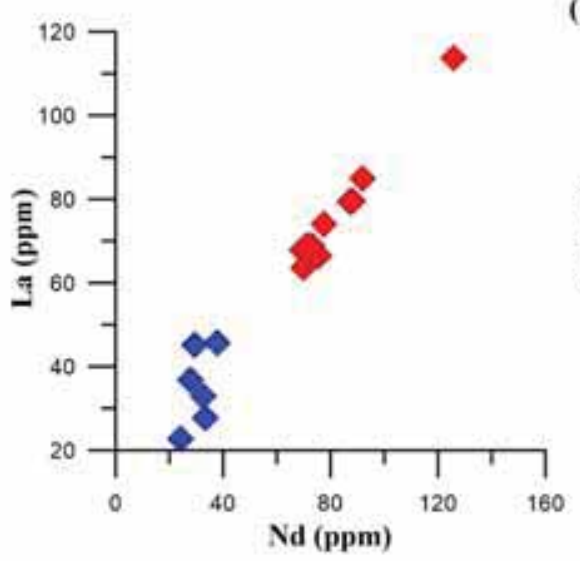

(c)

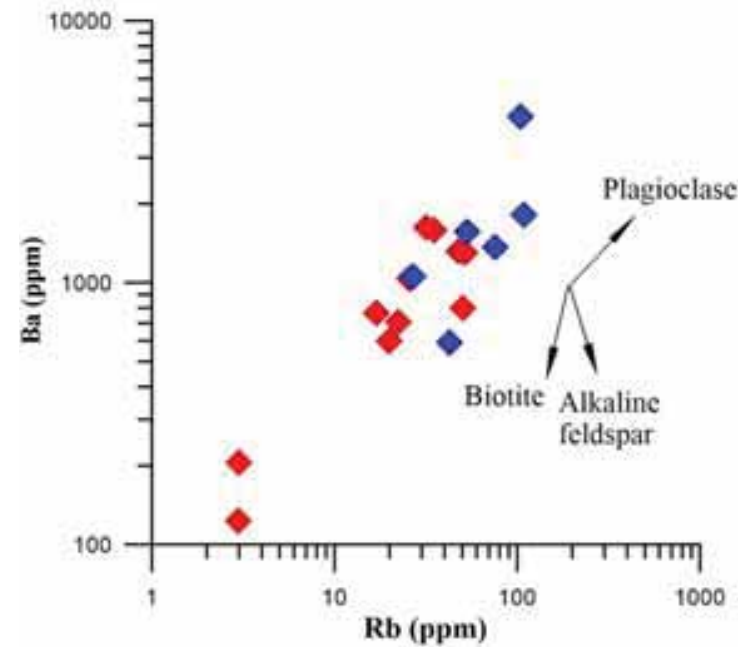

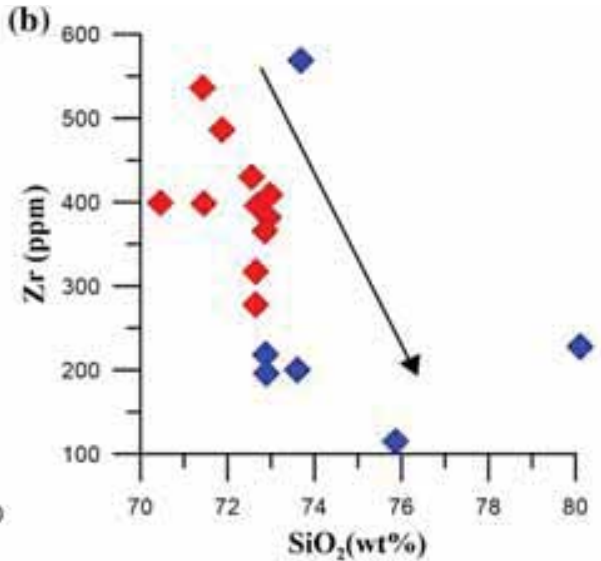

(d)

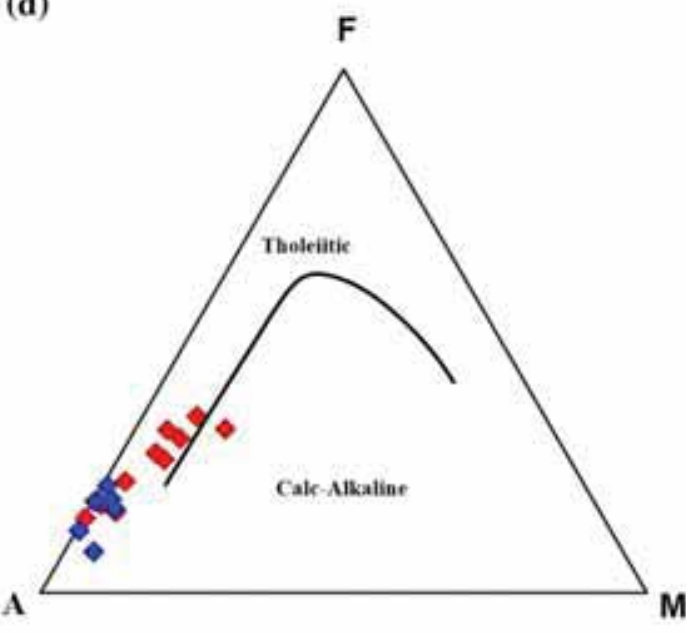

Figure 6. (a, b) Binary plots of La vs. $\mathrm{Nd}$ and $\mathrm{SiO}_{2}$ vs. Zr. (d) vector diagram of fractional crystallization (Rb vs Ba). (e) AFM diagram of Irvine and Baragar (1971) shows calc alkaline trend for Betul rhyolite.

REE with $(\mathrm{La} / \mathrm{Yb}) \mathrm{n}=2.2-8.7$ and $(\mathrm{Gd} / \mathrm{Yb}) \mathrm{n}=$ 0.6-1.6. LREE enrichment for both the groups also confirms the lower degree of partial melting of enriched source and/or they had interacted with continental crust (Ahmad et al. 2005). Very prominent negative $\mathrm{Eu}$ anomaly can be observed indicating fractionation of feldspar. Sakoli Rhyolite show almost similar REE pattern as Betul Rhyolite with LREE abundance 100-300 times chondritic abundance, which is little lower than LREE range of Group I Betul Rhyolite (figure 8a). But HREE abundance is almost same as the rhyolite of Group I making more moderate slope of REE pattern which can be because of comparatively higher degree of partial melting which is again confirmed in figure 7(a). Sakoli and Betul Rhyolite show Eu anomaly but is more prominent in the Sakoli samples. REE pattern for Bijli Rhyolite are highly fractionated and steep slope with $\mathrm{Eu}$ anomaly. LREE is highly enriched with 250-500 times the chondritic abundance indicating residual garnet in the source and LREE enriched source. Low degree of partial melting and/or crustal involvement may be responsible for the steep REE pattern of Bijli Rhyolite.

On Nb vs. Y diagram (after Pearce et al. 1984), all the rhyolites of Betul-Chhindwara belt plot along the transition line between WPG and ORG field (figure 7b). Even Sakoli Rhyolites also show similar characteristics, most of the samples in the ORG field, which is quite possible as they show almost same chemical composition. Sakoli Rhyolites has been studied as bimodal volcanism along with the basalt of the same area with $\mathrm{Sm}-\mathrm{Nd}$ age of rhyolite around $1675 \pm 180 \mathrm{Ma}$ (Ahmad et al. 2009b). All the rhyolite samples from Sakoli and Betul have affinity towards the ORG field, which indicates orogenic environment. So, we can propose that first there was subduction related volcanism, i.e., melting of mantle wedge, which produces Betul basalt (Alam et al. 2009) and after the interaction of that mafic melt with crustal sources, Group I 
(a)

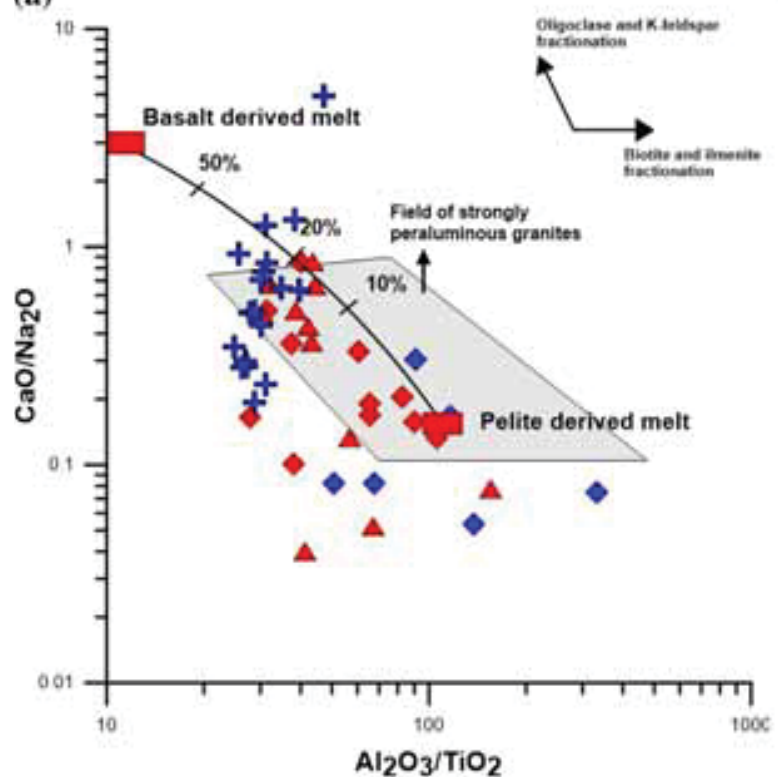

Betul Rhyolite Group I Betul Rhyolite Group II Sakoli acidic volcanic Bijli Rhyolite

(b)

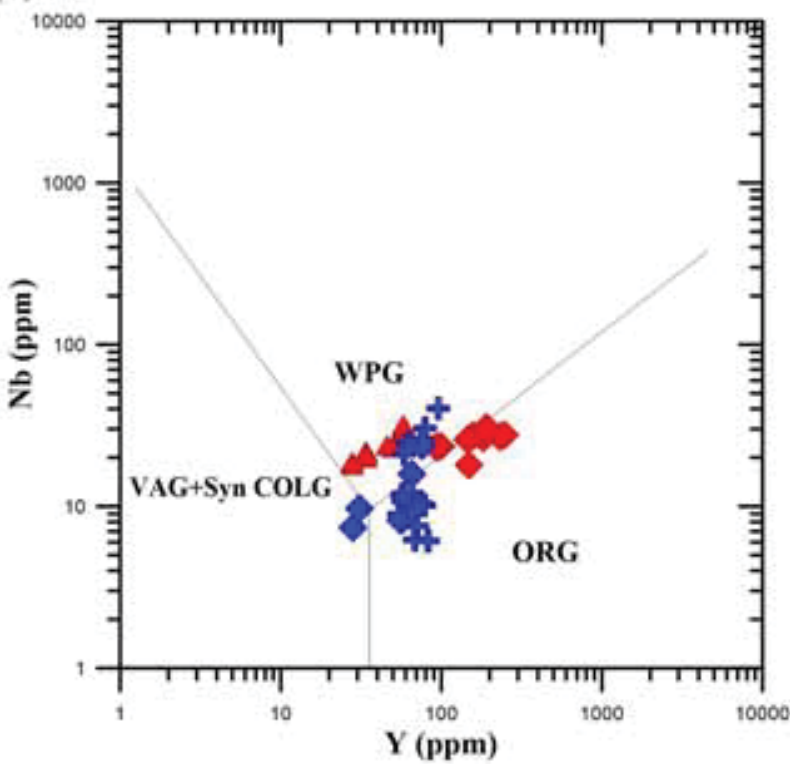

Figure 7. (a) $\mathrm{Al}_{2} \mathrm{O}_{3} / \mathrm{TiO}_{2}$ vs. $\mathrm{CaO} / \mathrm{Na}_{2} \mathrm{O}$ diagram of the Betul, Sakoli and Bijli Rhyolite derived from Wang et al. (2007). (b) Tectonic discrimination diagram Y vs. Nb for the felsic rocks from Betul-Chhindwara volcanic suite. Reference fields are from Pearce et al. (1984). Abbreviations. ORG: orogenic granites, syn-COLG: syncollision granites, VAG: volcanic arc granites, WPG: within-plate granites.

rhyolites have been produced. The upwelling in the mantle continued producing mafic volcanism which interacted with the crustal sources, which had already produced rhyolite, thus becoming less enriched gave rise to Group II rhyolites with lower enrichment off REE's. This sort of process probably explains the overall evolution of the bimodal volcanism in the Betul-Chhindwara belt. Samples of Bijli Rhyolite show plot in the WPG field, which indicates different tectonic setting (figure $7 \mathrm{~b}$ ). It is possible that Bijli Rhyolite must be associated with the rifting of the continental crust, which is also indicated by steep REE slope indicating involvement of crustal material to larger extent.

In figure 7(a), Bijli and Betul Rhyolite show a scattered pattern but most of the samples fall in the field of strongly peraluminous granite (Sylvester 1998). Group II of Betul Rhyolite have lower $\mathrm{CaO} / \mathrm{Na}_{2} \mathrm{O}$ ratio than all other rhyolites, probably indicating plagioclase poor source or more involvement of continental crust, whereas Sakoli Rhyolite have highest $\mathrm{CaO} / \mathrm{Na}_{2} \mathrm{O}$ ratio indicating plagioclase rich source (Chappell and White 1992; Sylvester 1998). Group I Betul Rhyolite, Sakoli Rhyolite and Bijli Rhyolite show a wide spread of samples in the diagram showing trend towards basalt derived melt. This trend indicates involvement of basalt and pelite which is very obvious in the bimodal volcanism. But Sakoli Rhyolite with lower $\mathrm{Al}_{2} \mathrm{O}_{3} / \mathrm{TiO}_{2}$ ratio than Bijli and Betul Rhyolite indicates presence of garnet in the source region, (figure 7a) and was generated at higher temperature and pressure than other rhyolites (Sylvester 1998).

Figure $8(\mathrm{~b})$ presents the primitive mantle normalized multi element pattern for the Betul, Bijli and Sakoli Rhyolite. Sakoli and Betul Rhyolite again show similar pattern just like REE pattern. Both displays moderately fractionated pattern with enrichment of large ion lithophile elements (LILE) - Rb, Ba, and $\mathrm{K}$ and strong negative anomaly of HFSE elements like $\mathrm{Nb}, \mathrm{P}$ and $\mathrm{Ti}$ (figure $8 \mathrm{~b}$ ). Sr exhibit a strong negative anomaly in the spider diagram which goes with the negative $\mathrm{Eu}$ anomaly in REE diagram as well indicating fractionation of feldspars. The negative $\mathrm{Nb}, \mathrm{P}$ and $\mathrm{Ti}$ anomaly of rhyolites of Betul-Chhindwara belt indicates collisional environment (Pearce et al. 1984; Ahmad and Tarney 1991). Even multi element diagram also show large variation in the abundance of most of the trace elements same like REE patterns, which confirm the variation in the degree of partial melting and/or crustal involvement (Ahmad et al. 2008a, b). Bijli Rhyolite 

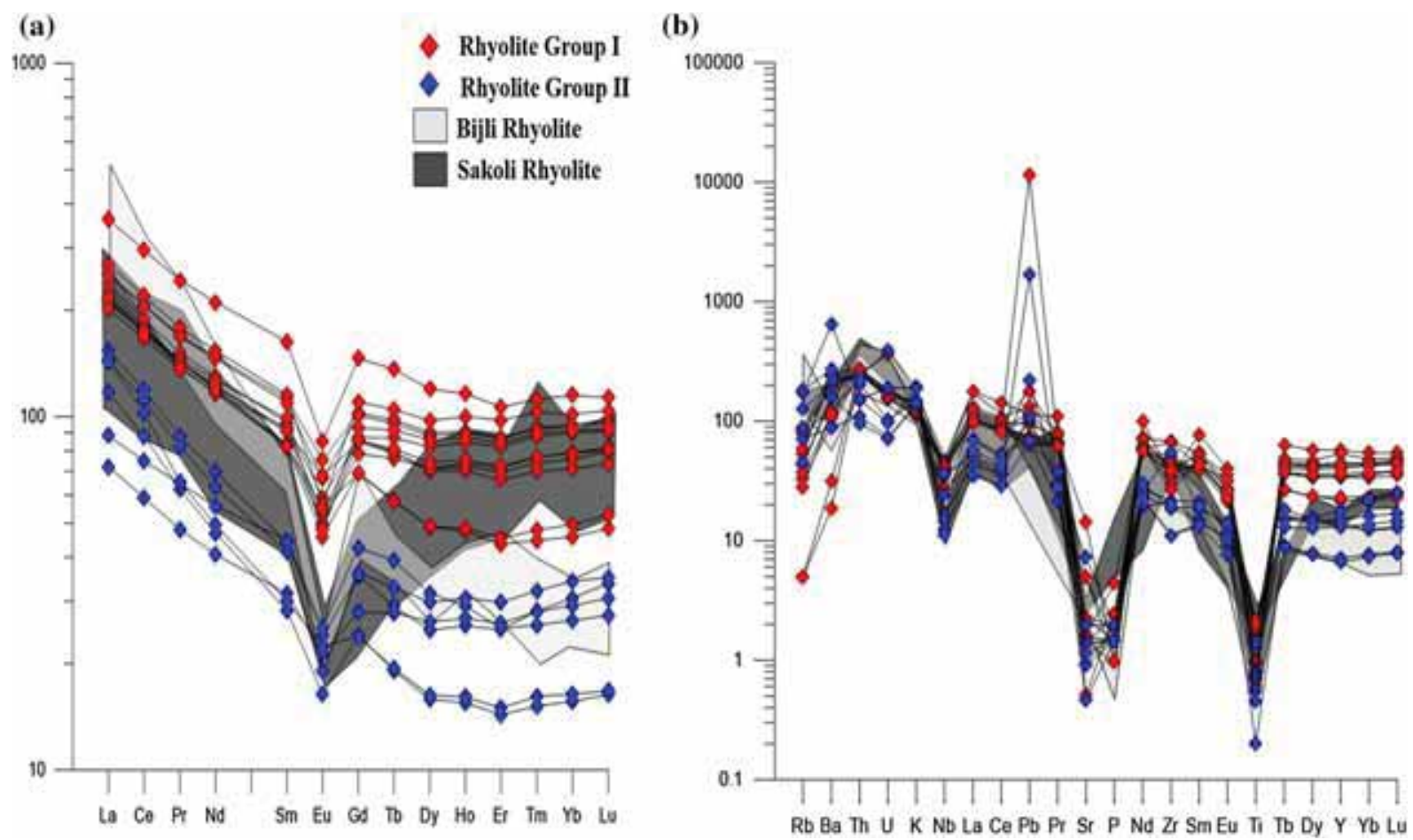

Figure 8. (a) Chondrite-normalized REE pattern, (b) Primitive mantle-normalized multi-element pattern for Betul, Sakoli and Bijli Rhyolite.

display comparatively more fractionated multi element pattern but almost follow the same pattern as Betul and Bijli Rhyolite. With same $\mathrm{Nb}, \mathrm{P}$ and Ti negative anomaly and high LREE-LILE we can assume the same tectonic setting but larger role of crust or more enriched source for the Bijli Rhyolite (Thompson et al. 1984; Ahmad and Tarney 1991).

Based on the data presented above we suggest that at first there was a partial melting in the mantle wedge which resulted in the generation of mafic magma. The mafic magma interacted with crustal sources while ascending, which caused lowering of the melting points of the crustal sources resulting in the generation of rhyolites with varying chemical characteristics. This process helped in producing rhyolite along with the mafic magma, resulting in bimodal volcanism in the Betul-Chhindwara belt (Huppert and Sparks 1988; Sparks et al. 1977; Ahmad et al. 2009b).

\section{8. $\mathrm{Nd}-\mathrm{Sr}$ isotopic characteristic of the studied samples}

Ten samples of Betul Rhyolites have been analyzed for their $\mathrm{Rb}-\mathrm{Sr}$ and $\mathrm{Sm}-\mathrm{Nd}$ ratios at the Department of Earth Sciences, Pondicherry University, India. Earlier geochronological studies have shown that younger country rock granite magmatism and suturing occurred around $1500 \mathrm{Ma}$ in the Central Indian Shield (Ahmad et al. 2010). As our studied rhyolite are assumed to be younger than $1.5 \mathrm{Ma}$ granites studied by Roy et al. (2004), we expect emplacement of acidic volcanic on the $1.5 \mathrm{Ma}$ country rock granite. As the generation of mafic magma progressed, it has led to the generation of rhyolites with different geochemical characteristics depending upon the depths they were generated and heterogeneity of the sources. Rb-Sr whole rock age of Bijli Rhyolite is $2180 \pm 25 \mathrm{Ma}$ (Sarkar et al. 1981) and 2503土35 Ma (Krishnamurthy et al. 1990), which are much older than Betul and Sakoli Rhyolite. This explains the enrichment of LREE in the Bijli Rhyolite which is derived from much enriched source. Whereas Betul and Sakoli have been derived from comparatively less enriched sources, which has already produced earlier batches of magma.

The initial ${ }^{87} \mathrm{Sr} /{ }^{86} \mathrm{Sr}$ value for the Group I rhyolites vary from $0.706412 \pm 3.6$ to $0.75295 \pm 3.5$ which is lower than the values of Group II rhyolites which vary from $0.734061 \pm 3.9$ to $0.917742 \pm 4.5$ (table 3). ${ }^{143} \mathrm{Nd} /{ }^{144} \mathrm{Nd}$ for Group I rhyolites which are enriched in REE's vary from $0.511985 \pm 1.7$ to $0.512138 \pm 1.8$ and for Group II rhyolites which are comparatively lower in REE's vary from 
(a)

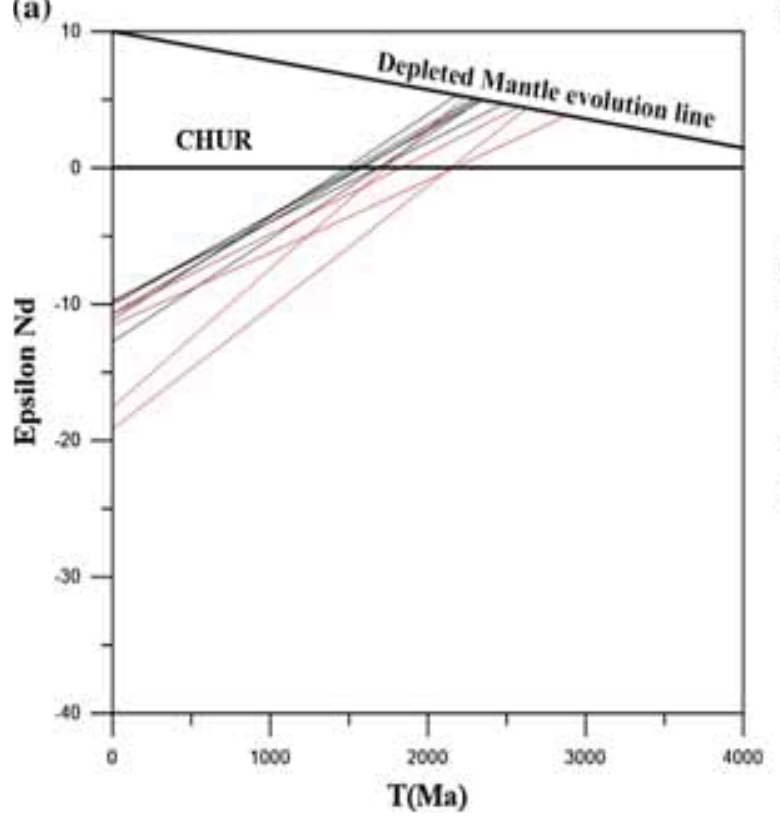

(b)

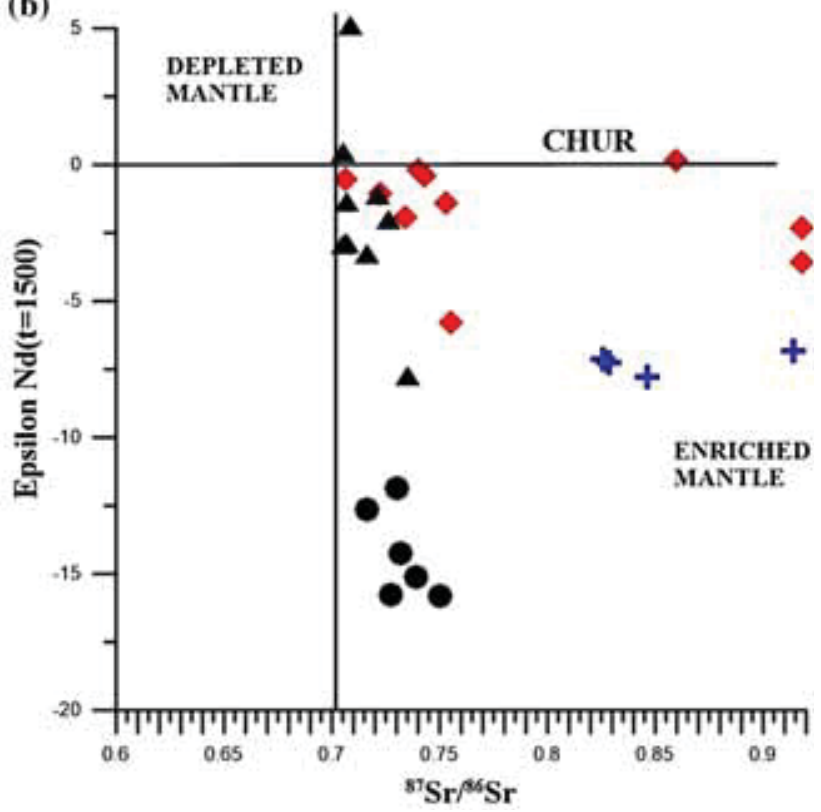

Figure 9. (a) $\varepsilon N d$ evolution trends for the Betul rhyolite samples of the Betul-Chhindwara volcanic suite. Note that at $\varepsilon$ Ndt $=$ 1500 both the groups of rhyolite plot away from the CHUR line indicating enriched source. Note both the groups of rhyolite can be distinguished. (b) Sr-Nd isotope plot for acidic rocks from Betul-Chhindwara belt. Granulite data taken from Alam et al. (2017), BGC data from Gopalan et al. (1990) and Sakoli rhyolite data taken from Ahmad et al. (2009b).

(a)

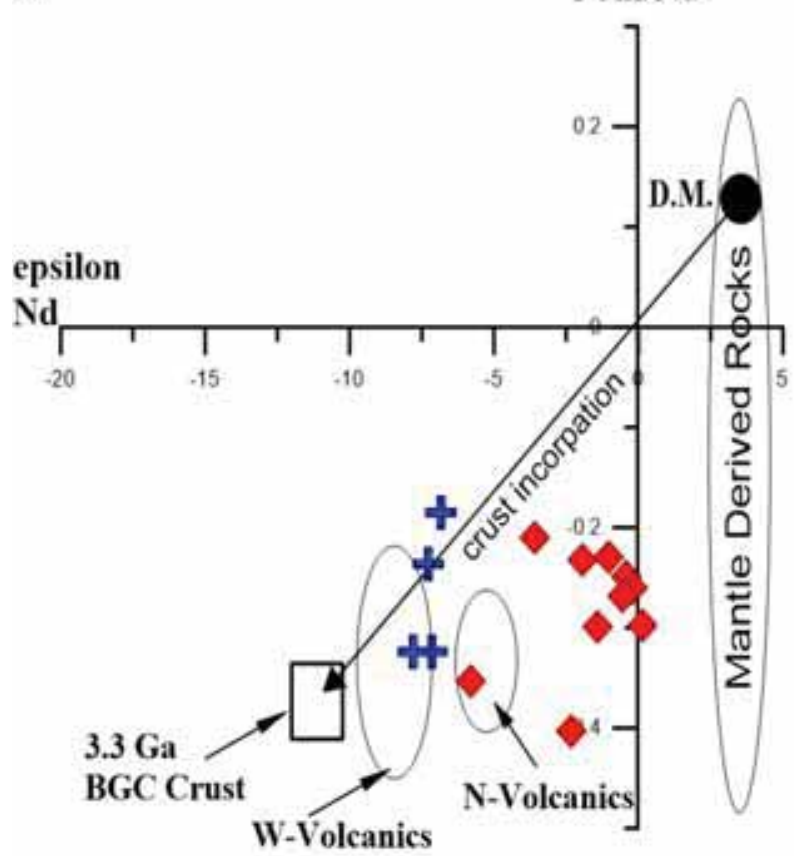

(b)

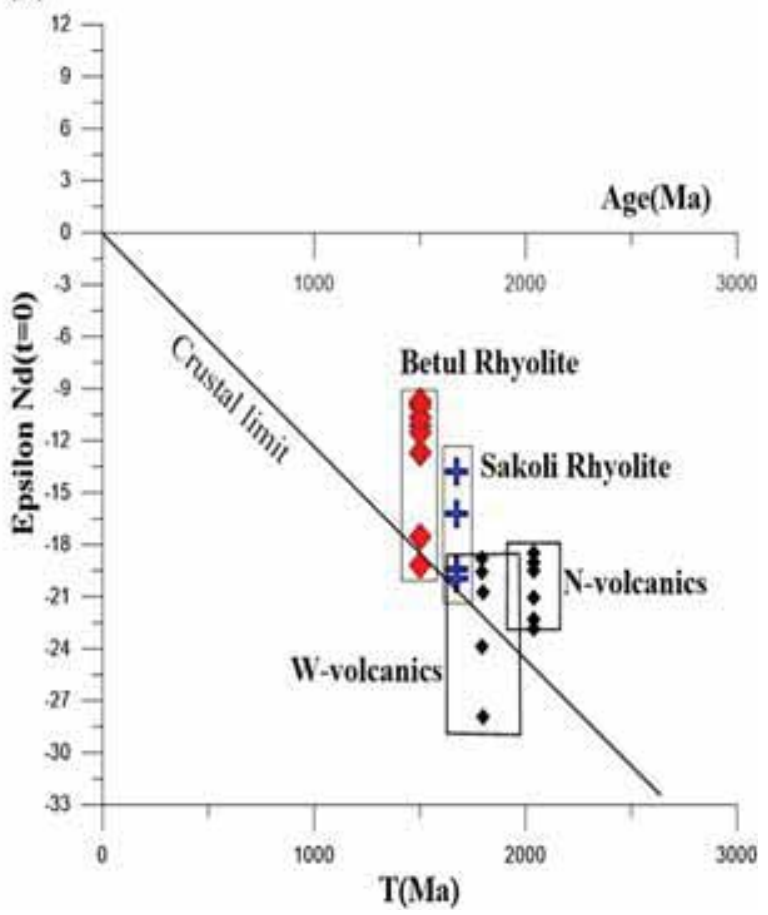

Figure 10. (a) $\varepsilon N d(1.5 \mathrm{Ga})$ vs. SSm/Nd diagram showing the Rhyolite of Betul-Chhindwara volcanic suite and Sakoli rhyolite in relation to the enriched source represented by $3.3 \mathrm{Ga}$ older crust (BGC from Gopalan et al. 1990), depleted pool (DM) and N-Volcanic field (after Ahmad et al. 2008a). (b) Discrimination diagram showing the present day Nd epsilon values for the acidic samples of Betul-Chhindwara volcanic suite in relation to other possible values vs. age. Data used from DePaolo (1981), V-and W-volcanic after Ahmad et al. (2008a). 


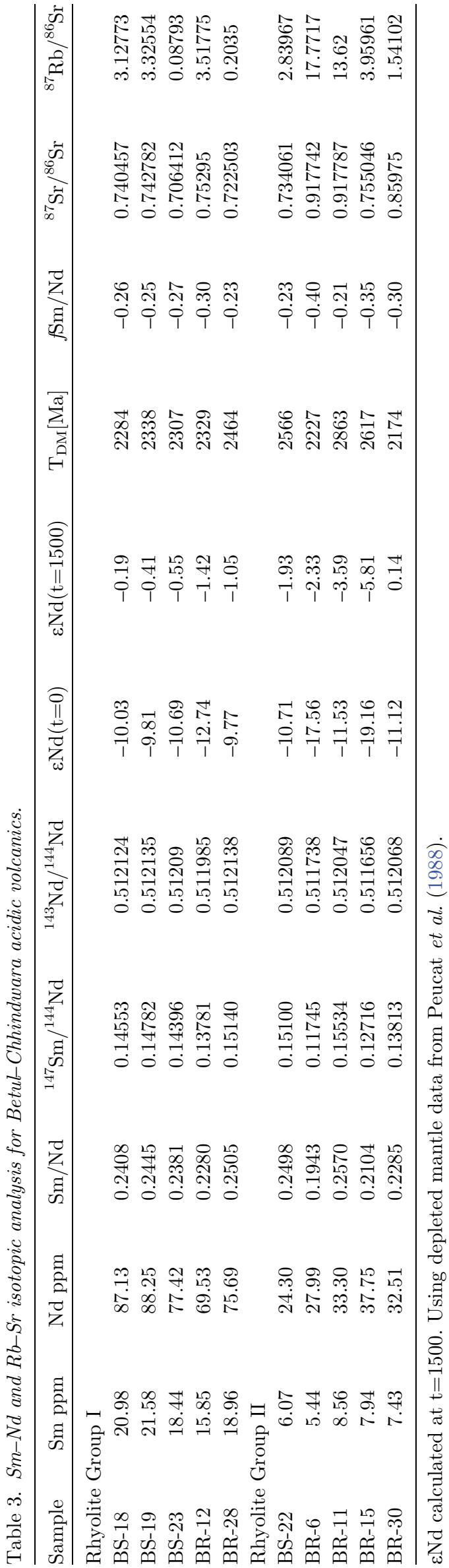

$0.511656 \pm 1.7$ to $0.512089 \pm 2.02$. In addition, the corresponding $\varepsilon N d t(t=1500)$ for the Group I rhyolites vary from -1.42 to -0.19 and for the Group II rhyolites vary from -5.81 to +0.14 . Calculated DM model ages for Group I rhyolites vary from 2284 to $2464 \mathrm{Ma}$ and for Group II vary from 2174 to 2863 Ma. The model ages of rhyolites are older, which indicates the extraction age of the protolith for the rhyolite would have separated from the mantle sources much earlier than the basaltic melts were generated. Higher negative $\varepsilon N d t$ values of rhyolites indicate that there was longer crustal residence time for their protoliths (Ahmad et al. 2009b). Sakoli rhyolite show much similarity with the Group II rhyolite of Betul-Chhindwara belt. ${ }^{87} \mathrm{Sr} /{ }^{86} \mathrm{Sr}$ value for Sakoli Rhyolite vary from 0.825919 to 0.914118 and calculated DM model ages vary from 2426 to 2777 (Ahmad et al. 2009b).

Both the group of rhyolites display much higher negative $\varepsilon N d t$ values and they plot below the CHUR line, which indicates enriched source for all the felsic samples (figure 9a). Both the rhyolite groups can be easily distinguished in the $\varepsilon N d$ vs. time diagram (figure 9a), which also confirms the heterogeneous source for both the group of rhyolites.

In order to understand the source and evolution of neodymium isotopic ratios we have plotted $\varepsilon \mathrm{Nd}$ $(\mathrm{t}=1500)$ against $\mathrm{fSm} / \mathrm{Nd}$ (figure 10a). Samples with low $\mathrm{Sm} / \mathrm{Nd}$ ratio will result into negative $\varepsilon \mathrm{Nd}$ and negative $f \mathrm{Sm} / \mathrm{Nd}$ as well. The samples with higher $\mathrm{Sm} / \mathrm{Nd}$ will evolve to more positive $\varepsilon N d$ with positive $\mathrm{fSm} / \mathrm{Nd}$ values with time (Shirey and Hanson 1986; Zachariah et al. 1995). Simple mixing of older continental crust and DM derived melt would show a crustal incorporation trend towards the older crust (3.3 Ga BGC basement gneisses: figure 10a) and will plot in lower left quadrant. Studied rhyolite plot in the lower left quadrant below the crustal incorporation trend is quite similar to the northern tholeiitic rocks of Nathdwara, Rajasthan (Ahmad et al. 2008a). The Aravalli meta-basalts have been derived from enriched source, which is evident in figure 10(a).

Interestingly, $\varepsilon N d$ values of Betul Rhyolite, northern and western volcanics of Nathdwara are very close to the crustal limit as described by DePaolo (1981) (figure 10b). Rock produced from an enriched mantle source shows very low $\varepsilon \mathrm{Nd}$ value and will lie close to or below the 'crustal limit' line. Like Betul Rhyolite many of the samples from Basal Aravalli volcanics show the same characteristics. Even Sakoli Rhyolite show similar 
trend as Betul Rhyolite with little age difference (figure 10b), indicating their derivation from enriched sources.

In the $\varepsilon \mathrm{Nd}(\mathrm{t})$ vs. ${ }^{87} \mathrm{Sr} /{ }^{86} \mathrm{Sr}$ diagram (figure $9 \mathrm{~b}$ ), rhyolites plot in the lower right quadrant indicating enriched mantle sources for rhyolites $\left({ }^{87} \mathrm{Sr} /{ }^{86} \mathrm{Sr}\right.$ $=0.706412-0.917787)$. It is observed that rhyolite do not show restricted plot for $\varepsilon \mathrm{Nd}(\mathrm{t})$ values and for ${ }^{87} \mathrm{Sr} /{ }^{86} \mathrm{Sr}$ ratio as well indicating more influence of crustal contamination. However, the rhyolite in general have much high ${ }^{87} \mathrm{Sr} /{ }^{86} \mathrm{Sr}$ ratio (0.706412-0.917787), which indicates the involvement of crustal components. The plot also shows the data of BGC from Rajasthan (Gopalan et al. 1990), which has very low $\varepsilon \mathrm{Nd}(\mathrm{t})(-18.346897$ to -14.335468), indicating longer crustal residence time. The BGC sample also show high ${ }^{87} \mathrm{Sr} /{ }^{86} \mathrm{Sr}$ ratio (0.716238-0.750418) indicating crustal involvement. The granulites from the CITZ (Alam et al. 2017) show their mantle extraction age same as rhyolite of Betul-Chhindwara Belt (granulite $\mathrm{T}_{\mathrm{DM}}$ 1.3-3.9 Ga) plot with the Betul Rhyolite (figure 9b). One of the samples of granulite plot in the depleted zone. However, Group II rhyolites of our study and Sakoli Rhyolite show very high ${ }^{87} \mathrm{Sr} /{ }^{86} \mathrm{Sr}$ ratio, which indicates crustal contamination as well as possibly enrichment of the source region. This may indicate re-melting of first generation of rhyolite/granite from this area which causes very high ${ }^{87} \mathrm{Sr} /{ }^{86} \mathrm{Sr}$ ratio for these rhyolite samples.

Differences in the geochemistry and isotopic data for the studied rocks clearly indicates that both the groups of rhyolites show a heterogeneous mantle source. Both the groups are not giving a good isochron, but they are giving an error-chron which is quite possible in case of bimodal volcanism. The error-chron explains that these rhyolites may be derived from the melting of the heterogenous crustal sources rather than melting of basalt alone. Difference in the enrichment of REE's in both the Groups of rhyolites indicates episodic partial melting of the heterogenous crustal sources, which cannot give an isochron is also observed in this study.

\section{Conclusion}

Geochemistry of the Betul-Chhindwara belt volcanic rocks includes mafic-felsic volcanics, occurring as flows, dykes, small bodies and lenses. Both the groups of felsic rocks show very strong negative Eu anomaly indicating the dominant feldspar fractionation. Enriched REE pattern indicates that these rhyolites have been derived from low degree partial melting of LREE-LILE enriched source or incorporation of crust while ascending to surface. These characteristics indicate typical collisional environment or Andean type subduction (Rolland et al. 2000, 2002).

Same pattern can be seen for Sakoli Rhyolite as well, but less enriched LREE and less fractionated REE pattern indicate higher degree of partial melting of the same source and can be considered contemporaneous to Betul Rhyolite. But Bijli

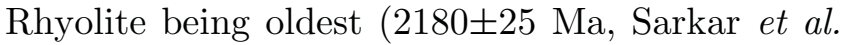

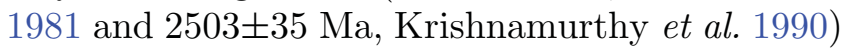
show highly fractionated REE pattern indicating enriched LREE source or involvement of crust to larger extent which is quite possible within plate magmatism. Bijli Rhyolite show different tectonic setting, i.e., within plate magmatism which makes it different from Sakoli and Betul Rhyolite.

Rhyolites are supposed to be generated by anatexis process driven by mafic magmas produced at the subduction zone. The fluids released from the subducting slab lowered the melting point of the mantle wedge, which produces mafic magma in the the Betul-Chhindwara belt. The mafic magma while ascending interacted with the continental crust at different levels to produce rhyolite of different geochemical characteristics. Mafic magma generated from enriched mantle source provided sufficient heat and fluids to lower down the melting point of continental crust/source regions, which results in production of rhyolites. Finally, both the magmas ascend contemporaneously resulting in the observed bimodal volcanism in the Betul-Chhindwara belt.

Partial melting of both mantle and crust with common thermal perturbation gave rise to mafic and felsic lava flows which got emplaced in the form of bimodal volcanism in the Betul-Chhindwara belt around 1.5 Ga.

Field relationships, lithological package and overall geochemical charachteristics using different discriminant diagrams and the enriched characteristics of incompatible trace elements including LREE and negative $\mathrm{Nb}$, $\mathrm{Ti}$, and $\mathrm{P}$ indicate that this bimodal volcanism of Betul-Chhindwara belt represent a continental arc setting.

\section{Acknowledgements}

The authors thank Mohammad Atif Raza, Senior Geologist, Faridabad GSI and Parvez Akhter, 
Senior Geologist, Bhopal GSI for making our field accessible and for guidance. Authors are grateful to Dr Satyanarayanan M, and Dr K S V Subramanyam, NGRI Hyderabad for their help in the geochemical analysis at NGRI, Hyderabad. They especially thank Dr Jitendra K Dash, Pondicherry University, Puducherry and Sminto Augustine, Research Scholar, Pondicherry University for all their support and help in the isotopic studies (CSIR-UGC-JRF Grant No. - 202504).

\section{References}

Acharyya S K 2000 Tectonothermal history of the Central Indian Tectonic Zone and reactivation of major faults/ shear zones; J. Geol. Soc. India 55 239-256.

Ahmad T and Tarney J 1991 Geochemistry and petrogenesis of Garhwal volcanics: Implications for evolution of the north Indian lithosphere; Precamb. Res. 50 69-88.

Ahmad T, Harris N B W, Islam R, Khanna P P, Sachan H K and Mukherjee B K 2005 Contrasting mafic magmatism in the Shyok and Indus Suture Zones: Geochemical constraints; Him. Geol. 26 33-40.

Ahmad T, Dragusanu C and Tanaka T 2008a Provenance of Proterozoic Basal Aravalli mafic volcanic rocks from Rajasthan, northwestern India: Nd isotopes evidence for enriched mantle reservoirs; Precamb. Res. 162 150-159.

Ahmad T, Tanaka T, Sachan H K, Asahara Y, Islam R, and Khanna P P 2008b Geochemical and isotopic constraints on the age and origin of the Nidar Ophiolitic Complex, Ladakh, India: Implications for the Neo-Tethyan subduction along the Indus suture zone; Tectonophys. 451 206-224.

Ahmad T, Kaulina T V, Wanjari N, Mishra M K and Nitkina E A 2009a U-Pb zircon chronology and Sm-Nd isotopic characteristics of the Amgaon and Tirodi Gneissic Complex, Central Indian Shield: Constraints on Precambrian crustal evolution; In: Precambrian continental growth and tectonism (eds) Singh V K and Chandra R, Excel India Publishers New Delhi, pp. 137-138.

Ahmad T, Longjam K C, Fouzdar B, Bickle M J and Chapman H J 2009b Petrogenesis and tectonic setting of bimodal volcanism in the Sakoli Mobile Belt, Central Indian Shield; Island Arc 18 155-174.

Ahmad T, Mishra M K, Longjam K C, Alam M, Joshi K B, Naushad M D, Devi S J, Dass K C and Kumar S 2010 Characterization of the Proterozoic mafic magmatism in the Central Indian Shield - Constraints on crustal evolution; In: National Symposium on Geology and Mineral Resources of Bundelkhand Craton (GMRB-2010) (eds) Bhatt S C and Singh S P, Abstract (Vol. 17).

Alam M, Naushad M, Wanjari N and Ahmad T 2009 Geochemical characterizations of mafic magmatic rocks of the Central Indian Shield: Implication for Precambrian crustal evolution; In: Geol. Anatomy of India and Middle East (eds) Ahmad T, Hirsch F and Charusiri P, J. Vir Expl. 8 1-12.

Alam M, Choudhary A K, Mouri H and Ahmad T 2017 Geochemical characterization and petrogenesis of mafic granulites from the Central Indian Tectonic Zone (CITZ); In: Crust-Mantle Interaction and Granitoid Diversification: Insights from Archaean Cratons (eds) Halla J, Whitehouse M J, Ahmad T and Bagai Z, Geol. Soc. London, Spec. Publ. 449 207-229.

Balaram V 1996 Recent trends in the instrumental analysis of rare earth elements in geological and industrial materials; Trends Anal. Chem. 15 475-486.

Bhowmik S K 1999 Evidence for Pre-Grenvillian high-pressure granulite metamorphism from the northern margin of the Sausar mobile belt in Central India; J. Geol. Soc. India 53 385-399.

Bhowmik S K and Pal T 2000 Petrotectonic implication of the granulite suite north of the Sausar mobile belt in the overall tectonothermal evolution of the Central Indian mobile belt; GSI Progress Report.

Bhowmik S K, Wilde S A and Bhandari A 2011 Zircon U-Pb/ Lu-Hf and monazite chemical dating of the Tirodi biotite gneiss: Implication for latest Palaeoproterozoic to Early Mesoproterozoic orogenesis in the Central Indian Tectonic Zone; Geol. J. 46 574-96.

Chappell B W and White A J R 1992 I- and S-type granites in the Lachlan Fold Belt; Trans. R. Soc. Edinb. Earth Sci. 83 $1-26$.

Chattopadhyay A, Bandyopadhyay B K and Khan A S 2001 Geology and structure of the Sausar fold belt: A retrospection and some new thoughts; Geol. Surv. India, Spec. Publ. 64 251-64.

Cox K G and Hawkesworth C J 1985 Geochemical stratigraphy of the Deccan Traps at Mahabaleshwar, Western Ghats, India, with implications for open system magmatic processes; J. Petrol. 26 355-377.

Cox K G 1988 Numerical modelling of a randomized RTF magma chamber: A comparison with continental flood basalt sequences; J. Petrol. 29 681-697.

DePaolo D J 1981 Neodymium isotopes in the Colorado Front Range and crust-mantle evolution in the Proterozoic; Nature 291193.

Dostal J, Wilson R A and Keppie J D 1989 Geochemistry of Siluro-Devonian Tobique volcanic belt in northern and central New Brunswick (Canada): Tectonic implications; Can. J. Earth Sci. 26 1282-1296.

Dupuy C and Dostal J 1984 Trace element geochemistry of some continental tholeiites; Earth Planet. Sci. Lett. 67 61-69.

Fodor R V, Sial A N, Mukasa S B and McKee E H 1990 Petrology, isotope characteristics, and $\mathrm{K}-\mathrm{Ar}$ ages of the Maranhao, northern Brazil, Mesozoic basalt province; Contrib. Mineral. Petrol. 104 555-567.

Gopalan K, Macdougall J D, Roy A B and Murali A V 1990 Sm-Nd evidence for 3.3 Ga old rocks in Rajasthan, northwestern India; Precamb. Res. 48 287-297.

Hogg A J, Fawcett J J, Gittins J and Gorton M P 1989 Cyclical variation in composition in continental tholeiites of East Greenland; Can. J. Earth Sci. 26 534-543.

Huppert H E, and Sparks R S J 1988 Melting the roof of a chamber containing a hot, turbulently convecting fluid; $J$. Fluid Mech. 188 107-131.

Irvine T N J and Baragar W R A 1971 A guide to the chemical classification of the common volcanic rocks; Can. J. Earth Sci. 8 523-548.

Jagadeesh S and Rai S S 2008 Thickness, composition, and evolution of the Indian Precambrian crust inferred from 
broadband seismological measurements; Precamb. Res. 162 $4-15$.

Jain S C, Nair K K K and Yedekar D B 1995 Geology of the Son-Narmada-Tapti lineament zone in central India; Geol. Surv. India, Spec. Publ. 10 1-154.

Kingson O, Bhutani R, Dash J K, Sebastian S and Balakrishnan S 2017 Resolving the conundrum in origin of the Manipur Ophiolite Complex, Indo-Myanmar range: Constraints from Nd isotopic ratios and elemental concentrations in serpentinized peridotite; Chem. Geol. 460 117-129.

Krishnamurthy P, Sinha D K, Rai A K, Seth D K and Singh S N 1990 Magmatic rocks of the Dongargarh Supergroup, central India - Their petrological evolution and implications on metallogeny; Geol. Surv. India, Spec. Publ. 28 303-319.

Le Bas M, Maitre R L, Streckeisen A and Zanettin B 1986 A chemical classification of volcanic rocks based on the total alkali-silica diagram; J. Petrol. 27 745-750.

Le Maitre RW, Streckeisen A, Zanettin B, Le Bas M J, Bonin B, Bateman P, Bellieni G, Dudek A, Efremova S, Keller J and Lamere J 2002 Igneous rocks: A classification and glossary of terms: recommendations of the International Union of Geological Sciences; In: Subcommission on the Systematics of Igneous rocks, Cambridge University Press.

Lippolt H J and Hautmann S $1994{ }^{40} \mathrm{Ar} /{ }^{39} \mathrm{Ar}$ ages of Precambrian manganese ore minerals from Sweden, India and Morocco; Mineral. Depos. 18 195-215.

Marsh J S 1989 Geochemical constraints on coupled assimilation and fractional crystallization involving upper crustal compositions and continental tholeiitic magma; Earth Planet. Sci. Lett. 92 70-80.

Mishra M K, Devi S J, Kaulina T, Dass K C, Kumar S and Ahmad T 2011 Petrogenesis and tectonic setting of the Proterozoic mafic magmatic rocks of the Central Indian Tectonic Zone, Betul area: Geochemical constraints; In: Dyke Swarms: Keys for Geodynamic Interpretation (ed.) Srivastava R K, Springer-Verlag, Heidelberg, pp. 189-201.

Mondal M E A, Goswami J N, Deomurari M P and Sharma K $\mathrm{K} 2002$ Ion microprobe ${ }^{207} \mathrm{~Pb} /{ }^{206} \mathrm{~Pb}$ ages of zircons from the Bundelkhand massif, northern India: Implications for crustal evolution of the Bundelkhand-Aravalli protocontinent; Precamb. Res. 117 85-100.

Nair K K K 1995 Stratigraphy, structure and geochemistry of the Mahakoshal greenstone; Geol. Soc. India Memoir 37 403-432.

O'Hara M J and Mathews R E 1981 Geochemical evolution in an advancing, periodically replenished, periodically tapped, continuously fractionated magma chamber; J. Geol. Soc. 138 237-277.

Pearce J A, Harris N B and Tindle A G 1984 Trace element discrimination diagrams for the tectonic interpretation of granitic rocks; J. Petrol. 25 956-983.

Peccerillo A and Taylor S R 1976 Geochemistry of Eocene calc-alkaline volcanic rocks from the Kastamonu area, northern Turkey; Contrib. Mineral. Petrol. 58 63-81.

Pegram W J 1990 Development of continental lithospheric mantle as reflected in the chemistry of the Mesozoic Appalachian tholeiites, USA; Earth Planet. Sci. Lett. 97 316-331.

Peucat J J, Vidal P, Bernard-Griffiths J and Condie K C 1988 $\mathrm{Sr}, \mathrm{Nd}$ and $\mathrm{Pb}$ isotpic systematics in the Archean low- to high-grade transition zone of southern India: Syn accretion vs. post-accretion granulites; J. Geol. 97 537-550.
Qureshy M N and Iqbaluddin 1992 A review of the geophysical constraints in modelling the Gondwana crust in India; Tectonophys. 212 141-151.

Radhakrishna B P and Naqvi S M 1986 Precambrian continental crust of India and its evolution; J. Geol. 94 145-166.

Radhakrishna B P and Ramakrishnan M 1988 Archaean Proterozoic Boundary in India; J. Geol. Soc. India $\mathbf{3}$ $263-278$.

Ramakrishnan M and Vaidyanadhan R 2008 Geology of India; Geol. Soc. India 1556.

Raut P K and Mahakud S P 2002 Geology, geochemistry and tectonic setting of volcano-sedimentary sequence of Betul belt, Madhya Pradesh and ore genesis of related Zinc and Copper sulphide mineralization. In: Proceedings of the National Seminar on Mineral Exploration and Resource Surveys, by Geological Survey of India, held at Jaipur.

Rolland Y, Pecher A and Picard C 2000 Middle Cretaceous back-arc formation and arc evolution along the Asian margin: The Shyok Suture Zone in northern Ladakh (NW Himalaya); Tectonophys. 325 145-173.

Rolland Y, Picard C, Pecher A, Lapierre H, Bosch D and Keller F 2002 The cretaceous Ladakh arc of NW Himalaya - slab melting and melt-mantle interaction during fast northward drift of Indian Plate; Chem. Geol. 182 139-178.

Roy A and Prasad M H 2003 Tectonothermal events in Central Indian Tectonic Zone (CITZ) and its implications in Rodinian crustal assembly; J. Asian Earth Sci. 22 115-129.

Roy A, Prasad M H and Bhowmik S K 2001 Recognition of pre-Grenvillian and Grenvillian tectonothermal events in the Central Indian Tectonic Zones: Implications on Rodinian crustal assembly; Gondwana Res. 4 755-757.

Roy A, Chore S A, Viswakarma L L and Chakraborty K 2004 Geology and petrochemistry of Padhar mafic-ultramafic complex from Betul Belt: A study on arc type magmatism in Central Indian Tectonic Zone; Geol. Surv. India, Spec. Publ. 84 297-318.

Sarkar S N, Gopalan K and Trivedi J R 1981 New data on the geochronology of the Precambrians of Bhandara-Drug, central India; Indian J. Earth Sci. 8 131-151.

Sensarma S, Hoernes S and Mukhopadhyay D 2004 Relative contributions of crust and mantle to the origin of the Bijli Rhyolite in a Palaeoproterozoic bimodal volcanic sequence (Dongargarh Group), central India; J. Earth Syst. Sci. 113 619-648.

Sheth H C 1999 A historical approach to continental flood basalt volcanism: Insights into pre-volcanic rifting, sedimentation, and early alkaline magmatism; Earth Planet. Sci. Lett. 168 19-26.

Shirey S B and Hanson G N 1986 Mantle heterogeneity and crustal recycling in Archean granite-greenstone belts: Evidence from Nd isotopes and trace elements in the Rainy Lake area, Superior Province, Ontario, Canada; Geochim. Cosmochim. Acta 50 2631-2651.

Sparks S R, Sigurdsson H and Wilson L 1977 Magma mixing: A mechanism for triggering acid explosive eruptions; Nature 267315.

Sylvester P J 1998 Post-collisional strongly peraluminous granites; Lithos 45 29-44.

Thompson R N, Morrison M A, Hendry G L and Parry S J 1984 An assessment of the relative roles of crust and mantle 
in magma genesis: an elemental approach; Philos. Trans. R. Soc. Lond. Ser. A 310 549-590.

Van Wagoner N A, Leybourne M I, Dadd K A, Baldwin D K and McNeil W 2002 Late Silurian bimodal volcanism of southwestern New Brunswick, Canada: Products of continental extension; Geol. Soc. Am. Bull. 114 400-418.

Verma R K and Banerjee P 1992 Nature of continental crust along the Narmada-Son Lineament inferred from gravity and deep seismic sounding data; Tectonophys. 202 375-397.

Wang Y, Fan W, Sun M, Liang X, Zhang Y and Peng T 2007 Geochronological, geochemical and geothermal constraints on petrogenesis of the Indosinian peraluminous granites in the South China Block: A case study in the Hunan Province; Lithos 96 475-502.
Winchester J and Floyd P A 1977 Geochemical discrimination of different magma series and their differentiation products using immobile elements; Chem. Geol. 20 $325-343$.

Yedekar D B 1990 The central Indian collision suture; Geol. Surv. India, Spec. Publ. 28 1-43.

Yedekar D B, Karmalkar N, Pawar N J and Jain S C 2003 Tectonomagmatic evolution of Central Indian terrain; Gondwana Geol. Mag. Spec. 7 67-88.

Zachariah J K, Hanson G N and Rajamani V 1995 Postcrystallization disturbance in the neodymium and lead isotope systems of metabasalts from the Ramagiri schist belt, southern India; Geochim. Cosmochim. Acta $\mathbf{5 9}$ $3189-3203$.

Corresponding editor: N V CHALAPathi RaO 